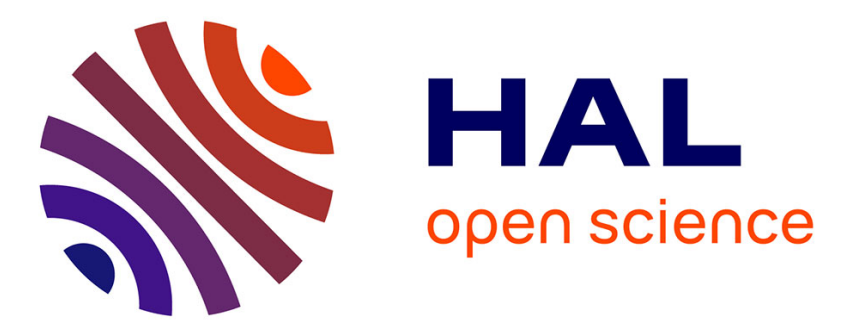

\title{
Dietary changes and millet consumption in northern France at the end of Prehistory: evidence from archaeobotanical and stable isotope data.
}

Gwenaëlle Goude, Léonie Rey, Françoise Toulemonde, Mathilde Cervel, Stéphane Rottier

\section{To cite this version:}

Gwenaëlle Goude, Léonie Rey, Françoise Toulemonde, Mathilde Cervel, Stéphane Rottier. Dietary changes and millet consumption in northern France at the end of Prehistory: evidence from archaeobotanical and stable isotope data.. Environmental Archaeology, 2017, 22 (3), pp.268-282. 10.1080/14614103.2016.1215799 . hal-01650950

\section{HAL Id: hal-01650950 https://hal.science/hal-01650950}

Submitted on 19 Nov 2020

HAL is a multi-disciplinary open access archive for the deposit and dissemination of scientific research documents, whether they are published or not. The documents may come from teaching and research institutions in France or abroad, or from public or private research centers.
L'archive ouverte pluridisciplinaire HAL, est destinée au dépôt et à la diffusion de documents scientifiques de niveau recherche, publiés ou non, émanant des établissements d'enseignement et de recherche français ou étrangers, des laboratoires publics ou privés. 


\section{Dietary changes and millet consumption in northern France at the end of Prehistory: Evidence from archaeobotanical and stable isotope data}

Gwenaëlle Goude, Léonie Rey, Françoise Toulemonde, Mathilde Cervel \& Stéphane Rottier

To cite this article: Gwenaëlle Goude, Léonie Rey, Françoise Toulemonde, Mathilde Cervel \& Stéphane Rottier (2017) Dietary changes and millet consumption in northern France at the end of Prehistory: Evidence from archaeobotanical and stable isotope data, Environmental Archaeology, 22:3, 268-282, DOI: 10.1080/14614103.2016.1215799

To link to this article: http://dx.doi.org/10.1080/14614103.2016.1215799 


\title{
Dietary changes and millet consumption in northern France at the end of Prehistory: Evidence from archaeobotanical and stable isotope data
}

\author{
Gwenaëlle Goude ${ }^{1}$, Léonie Rey ${ }^{2}$, Françoise Toulemonde ${ }^{3}$, Mathilde Cervel4, \\ Stéphane Rottier ${ }^{2}$
}

${ }^{1}$ Aix Marseille Univ, CNRS, Minist Culture \& Com, LAMPEA, Aix-en-Provence, France, ${ }^{2}$ Université de Bordeaux,
CNRS, Ministère de la culture et de la communication, Pessac Cedex, France, ${ }^{3}$ UMR 7209 CNRS/MNHN, Paris,
France, ${ }^{4}$ Ecole Pratique des Hautes Etudes, Paris Cedex, France

Diachronic changes of dietary human habits between the Neolithic and the Bronze Age are mainly identified through archaeological artefacts and archaeozoological and archaeobotanical studies. This paper aims to demonstrate the importance of a multi-disciplinary approach for palaeodietary studies and to identify the food changes between Neolithic and Bronze Age human groups in northern France. These changes are probably linked to the introduction of new crops, such as millet, and the use of stable isotope analysis on bones and teeth proves to be an effective method for assessing the role of this specific cereal in the diet and the economy. Stable isotope analyses were performed on bone and tooth collagen and apatite from eight humans and five domestic animals from a Late Bronze Age site (LBA; Barbuise; 15th-13th c. BC; Aube). The studied corpus is compared with isotopic data from human and animal bones from a nearby Neolithic site (Gurgy; 5th mill. BC; Yonne) and regional Neolithic to Iron sites located in northern France. Moreover, Barbuise data are supplemented by information from an important archaeobotanical study carried out on 21 LBA and Early Iron Age sites in the region. Neolithic and LBA human collagen isotopic ratios $\left(\delta^{13} \mathrm{C}, \delta^{15} \mathrm{~N}\right)$ differ statistically, as do those of some animals. Carbon isotopic ratios of human apatite corroborate collagen results indicating the consumption of ${ }^{13} \mathrm{C}$ enriched food by LBA humans and animals compared to Neolithic samples. The high number of occurrences of plant remains in the Bronze Age settlements near the site points to the consumption of $\mathrm{C}_{4}$ plants, such as millet, and would account for these results.

Keywords: Stable isotope, Archaeobotany, Millet, Neolithic, Bronze Age, France

\section{Introduction}

\section{Archaeological contexts}

Ancient diet studies efficiently document the socio-cultural changes that have occurred during the main Prehistoric transition phases. Stable isotope analysis is now recognised as an essential method to track individual/human group subsistence strategies. One of the numerous examples is the Mesolithic-Neolithic transition, which has been extensively assessed since the reference works of Tauber (1981) and Schoeninger et al. (1983). The strong decrease in the bone carbon isotope ratio observed between Mesolithic and Neolithic humans along the Atlantic coast indicates a new food acquisition pattern linked to the arrival and

Correspondence to: Gwenaëlle Goude, Aix Marseille Université, CNRS, Ministère de la culture et de la communication, LAMPEA UMR 7269, MMSH - 5 rue du Château de l'Horloge, 13094, Aix-en-Provence, France. E-mail: goude@mmsh.univ-aix.fr development of agriculture and herding (Richards 2003; Richards and Hedges 1999; Richards and Schulting 2003; Schulting and Richards 2002), and recent data from archaeological artefacts corroborate these studies (Cramp et al. 2014). On the other hand, a less contrasted pattern was proposed for some inland areas, where freshwater resources played a significant role in the subsistence economy at the beginning of the Neolithic while cereal cultivation was not clearly attested (Bonsall et al. 2000; 2004; Boric et al. 2004; Nehlich et al. 2010).

Protohistorical periods are also of major interest to archaeologists and anthropologists as new trade exchanges (e.g., salt), the material economy (e.g., metallurgy), migrations and crops, followed by demographic increase and the development of chiefdoms and hierarchy (e.g., Earl and Kristiansen 2010; Guilaine 2007; Harding 2000; Kristiansen and 
Rowlands 1998; Rottier et al. 2012) probably had an impact on diet. Diachronic changes in human habits between the Neolithic and the Bronze Age are well documented in the archaeological record (e.g., Harding and Fokkens 2013; Tarrête and Le Roux 2008). Environmental modifications, climatic deterioration between 1550 and 1350 BC (Magny 2004; Magny et al. 2007), during the transition between the Middle and Late Bronze Age (LBA), also prompted Bronze Age populations to adapt to different cultivation conditions (Richard et al. 2007). In Western Europe, human groups occupied new territories from the beginning of the Neolithic (end of the 6 th to the beginning of the 5th mill. BC), basing their subsistence economy on a new way of life including animal herding and plant cultivation. Neolithic societies settled and exploited these environments more intensively during the middle Neolithic (5th4th mill. BC). During the end of the Neolithic and the transition to the Bronze Age (3rd mill. BC), long distance trade began to develop and human groups profoundly changed their social organisation (Besse 2007; Guilaine 2007; Kristiansen 1998; Rowlands 1998). Other modifications are also evidenced by the advent of metallurgy, leading mainly to different trading practices according to raw material availability (copper, then tin in particular) and the place where they were worked (Harding and Fokkens 2013). It seems that, during the Neolithic, most of the exchanges took place step by step, strengthening relationships with neighbours. On the other hand, at the end of the Neolithic and during the Bronze Age, trade exchanges increased and covered wider areas more quickly. Archaeological records from the second half of Bronze Age substantiate this pattern, particularly with regard to the domestication of horses (Harding and Fokkens 2013).

This study focuses on the south-eastern part of the Paris Basin, which remained a major cultural intersection throughout these four millennia, due to the merging of the Danube and Mediterranean neolithisation routes and of the North-Alpine and Atlantic complexes. This cultural crossroads then shifted towards the South along the Rhône valley. Cultural exchanges thus changed over time and could possibly also have modified dietary patterns. In France, diachronic studies have rarely been conducted using stable isotope analyses on human bones and teeth. Moreover, the comparison of archaeobotanical and anthropological data is still under-developed in this region. Our paper aims to assess the potential dietary changes between the Neolithic and Protohistoric periods in relation with the spread of millet and to document the role of this crop in the Bronze Age economy in northern France. The study focuses on a LBA site, Barbuise, by using stable isotope analysis.
Isotopic data of Barbuise are compared to available data sets from (1) a Neolithic regional site, Gurgy, and (2) Neolithic to Iron Age sites located in the northern half of France.

\section{The LBA funerary complex of Barbuise}

The funerary group of Barbuise and La Saulsotte (Aube, France), located in the south-eastern part of the Paris Basin, includes the most important human bone collection (ca. 150 burials) dated to the beginning of the LBA (15th-12th c. BC) in the northern half of France. This funerary group is part of a cultural system with more than 30 funerary sites discovered in a confined area. In this area, funerary practices appeared to diversify during the transition between the Middle and the LBA. Cremations became more frequent while burial types were more and more diversified (Rottier et al. 2012). Besides cremations, two main tomb categories have been described: one with a long pit where the deceased is lying down and one with a shorter-sized pit where the deceased is vertically crouched (Rottier 2004). Despite the variability of these practices, all the burials are managed in similar and standardised ways with bone removal after the burial (Rottier 2009, 2011). Bone removals could have been performed while the corpse was rotting or when decomposition was finished (Rottier 2012, 2016). Up to now, this funerary practice is known only in the southeast of the Paris basin (Rottier et al. 2012). This phenomenon leads to a severe lack of skeletal elements, particularly for pelvis and cranium bones, sometimes restricting biological studies. Moreover, immature individuals are often missing from the site. The identification of "local" versus "non-local" individuals is proposed according to the grave goods (several publications detail the different funerary items; Rottier 2015; Rottier et al. 2012), and the bone morphometric study did not differentiate biological groups (Rottier et al. 2012). The archaeological records indicate an allochthonous origin for some of the material with central European influences. Long distance trade and contacts are well known for this period, including the widespread exchange of goods and raw materials. The archaeo-anthropological study carried out at Barbuise highlighted a possible foreign origin for some of the individuals inhumed here (Rottier et al. 2012).

\section{The archaeobotanical data}

A recent archaeobotanical synthesis of 272 settlement sites and 375 Bronze Age occupations in France (Bouby et al. in press) reported that millet cultivation expanded greatly on French territory during the LBA (the species involved are broomcorn millet Panicum miliaceum - and to a lesser extent foxtail millet - Setaria italica). This phenomenon is 
particularly remarkable and precocious in northeastern France. This was most probably enhanced by cultural influences and exchanges within the northalpine complex, linking during the Middle and the LBA this part of the present French territory to central Europe. Millet cultivation is already well developed in central Europe during the middle Bronze Age, and may have spread from this area to other parts of Europe during the end of the Middle/beginning of the LBA (Stika and Heiss 2013).

Broomcorn millet is noted occasionally on the French territory from the Early Bronze Age (EBA) onwards, but gaps in the data for this period and for the subsequent Middle Bronze Age do not allow for a full understanding of how and exactly when during the Bronze Age this cereal gained economic significance. In north-eastern France, in an area of less than one hundred kilometres around the site of Barbuise, an archaeobotanical study conducted on 21 LBA and Early Iron Age settlements (FerrageToulemonde 2013; Toulemonde et al. forthcoming) has shown that during this period (1350-460 BC), millet, and especially broomcorn millet, had real economic significance and definitely contributed widely to the human diet. Food production was based on a highly diversified spectrum of cultivated species, including ten cereals (different species of barley, wheat and millet), four pulses and three oil plants. Staple crops were mainly cereals. Hulled barley (Hordeum vulgare) was the most important, but millet also played an important role in production. All but one of the 21 analysed settlements yielded broomcorn millet, sometimes in large quantities and with high ubiquity (Fig. 1): caryopses of millet were found in $57 \%$ of the 421 analysed samples, and represented $23 \%$ of the total of the remains (compared to $79 \%$ of the samples and $24 \%$ of the remains for barley). Millet was particularly frequent and abundant in the upper Seine valley, where the LBA cemetery of Barbuise is located, since the beginning of the LBA. So even if archaeobotanical study was not performed directly on vegetal remains from Barbuise, we can assume that millet was cultivated by the inhabitants of Barbuise, as this cereal was grown everywhere else in the area.

Stable isotope analysis and diet: a brief review In bone tissues, the recorded stable isotope ratios are linked to ingested food and water with a differentiation between collagen, which is mainly formed from the protein in the diet and apatite carbonate, derived from blood $\mathrm{CO}_{2}$, which reflects all of the consumed energy (i.e., carbohydrates, fats and the rest of the protein not used for collagen; Ambrose and Norr 1993). At the base of the food chain, plants have specific $\delta^{13} \mathrm{C}$ and $\delta^{15} \mathrm{~N}$ ratios according to climatic and edaphic conditions (e.g. Ambrose and De Niro 1989; Mariotti 1982), photosynthetic pathways (Farquhar et al. 1989) and species (Virginia and Delwiche 1982). In particular, this study focuses on $\delta^{13} \mathrm{C}$ which is different in $\mathrm{C}_{3}$ plants (such as wheat and barley) and $\mathrm{C}_{4}$ plants (such as maize and millet), allowing for differentiation between the consumers of these plants located far from coastal environments (e.g. Ambrose et al. 2003). Herbivore bone collagen registers the $\delta^{13} \mathrm{C}$ of the plant consumed, with an enrichment of ca. 5\%o and the difference between the bone collagen of a prey and predator (i.e., herbivorecarnivore) is ca. $0-1 \%$. The nitrogen isotopic ratio is also an environmental marker and is mainly used for differentiating marine vs. terrestrial environments (Schoeninger and DeNiro 1983) and detecting the trophic level of an individual, as the difference observed between prey-predator bone collagen is ca. 3-5\% (see up to 6\%) (Bocherens and Drucker 2003; O'Connell et al. 2012). The study of both $\delta^{13} \mathrm{C}$ and $\delta^{15} \mathrm{~N}$ in human bone collagen thus provides information on the environment exploited, preferentially consumed plant types and the relative quantity of ingested animal protein, provided that the range of values defining the local environment based on animal and/or botanical isotopic data is known (e.g. Herrscher and Le Bras-Goude 2010).

In human bone and tooth, apatite carbonate is derived from blood $\mathrm{CO}_{2}$ and reflects bulk energy, including carbon from non-protein sources and the remaining carbon from amino acids not used to synthesise protein (Ambrose and Norr 1993; Krueger and Sullivan 1984). Apatite $\delta^{13} \mathrm{C}$ is enriched by ca. 9.4\% compared to the diet (Ambrose et al. 1997). Contrary to collagen, $\delta^{13} \mathrm{C}$ in apatite carbonate provides information on the low protein sources consumed, such as cereals or molluscs, for example (Ambrose and Norr 1993). The combination of both collagen and apatite isotope ratios adds a wider perspective to the study of the human diet as proposed by Ambrose et al. $(1997 ; 2003)$ and by Kellner and Schoeninger (2007), particularly regarding the consumption of $\mathrm{C}_{4}$ resources. The measurement of oxygen isotopic ratios in apatite carbonate has often been used to track the geographic origin and mobility of humans (e.g. Iacumin et al. 1996). Indeed, $\delta^{18} \mathrm{O}$ in ground water sources is linked to different geographic parameters such as latitude, altitude and temperature (Longinelli 1984). For example an individual living in a mountainous area would show a lower $\delta^{18} \mathrm{O}$ ratio than a person living in a coastal environment (e.g. Knudson 2009). However, several factors highlight the difficulties in effectively using this proxy in archaeological human bone tissue from European areas: apatite carbonate preservation, lack of discriminating $\delta^{18} \mathrm{O}$ ratios in a wide area of the European 


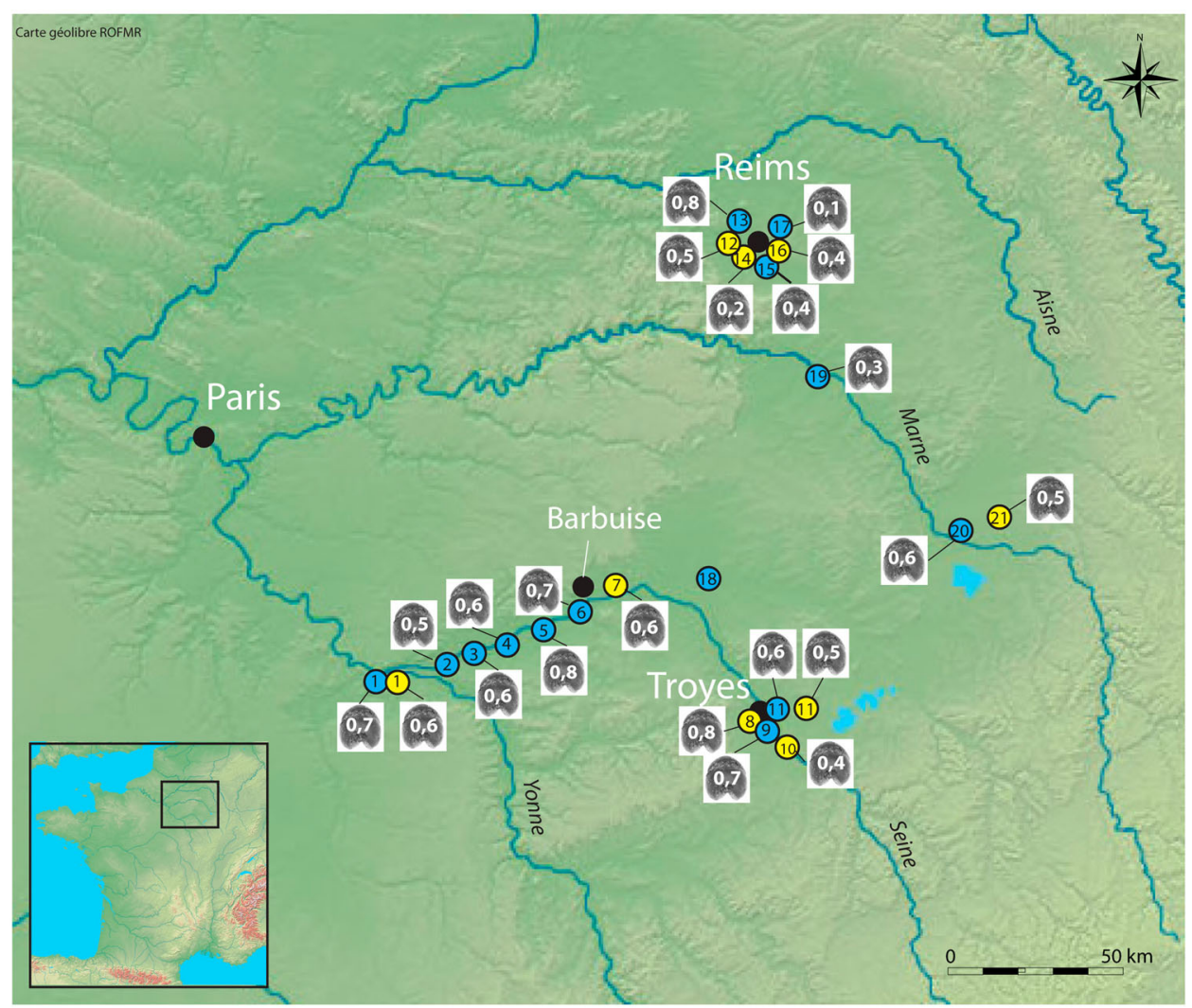

1-Ville-St-Jacques "Le Fond des Vallees" "'Le Bois d'Echalas"; 2-Balloy "La Haute Borne"; 3-Jaulnes "Le Bas des Hauts Champs-Ouest ;4-Noyen-sur-Seine "Le Nord du Bois du Chêne" ; 5-Villiers-sur-Seine "Le Gros Buisson"; ;-Pont-sur-Seine "La Gravière" ; 7-Périgny-la-Rose "Pampeleine"; 8-St-André-les-Vergers "Echenilly"; Terres Soudées"; 13-Thillois "La Croix Rouge"; 14-Bezannes "La Bergerie"; 15-Cormontreuil "Les Grands Godets"; 16-Reims "Zac Croix Blandin"; 17-Bazancourt-Pomacle "Sur les Petits Poissons"; ;18-Plancy-l'Abbaye "Saint Martin"; 19-St Martin-sur-le-Pré "Rue des Castors"; 20-Matignicourt-Goncourt "Les Brouillards" ; 21-Thiëblemont-Farémont "RN4 Echangeur".

Late Bronze Age settlement (1350-800 BC) ( $X=n^{\circ}$ of settlement)

(X) Early Iron Age settlement (800 - 460 BC)

Cultivation of broomcorn millet. $X=$ Ubiquity $=$ proportion of contexts with millet $(\max =1)$

territory and the significant increase in $\delta^{18} \mathrm{O}$ ratios in "anthropic" beverages (e.g. tea) and cooked products (e.g. soup), compared to ground water (Brettell et al. 2012). For these reasons, the $\delta^{18} \mathrm{O}$ ratio will not be included in the analysis of our data.

\section{Samples and analyses}

Our study focused on both human and animal remains from the LBA of Barbuise. The analyses of different animal bones allowed us to define a range of values for a specific environment and a known diet and thus to interpret the human data (e.g. Goude and Fontugne 2016). Isotopic analyses were performed on eight human bones and teeth (five females and three males; due to skull removals in most of the burials, there were only few individuals available with both bone and teeth; Rottier et al. 2012), as well as five animals (two pigs, two horses and one dog). Sex determination was performed by using morphoscopic and morphometric methods (Bruzek 2002;
Murail et al. 2005) and age at death was estimated by using bone maturation. In order to (1) compensate for the small sample size of animal remains studied and (2) attempt diachronic comparisons, data from other sites located in the centre and north of France were also used (Neolithic animal remains: Balasse et al. 1997; Balasse 1999; Balasse et al. 2000; Bocherens et al. 2000; Neolithic to Iron Age human and animal remains: Goude et al. 2014; Herrscher et al. 2013; Le Bras-Goude et al. 2011; Fig. 2). For humans, both bone and M2 root were selected. Due to permanent remodelling, bone tissues provide information on the last years of life. The remodelling is faster during infancy and strongly diminishes with the passing years (Valentin 2003). The LBA samples only come from adults, thus the isotopic signal recorded in bone represents average food consumption during adulthood. On the other hand, the M2 root mainly grows during childhood and the apex closes during adolescence (ca. 6-14 years old; Schaefer 


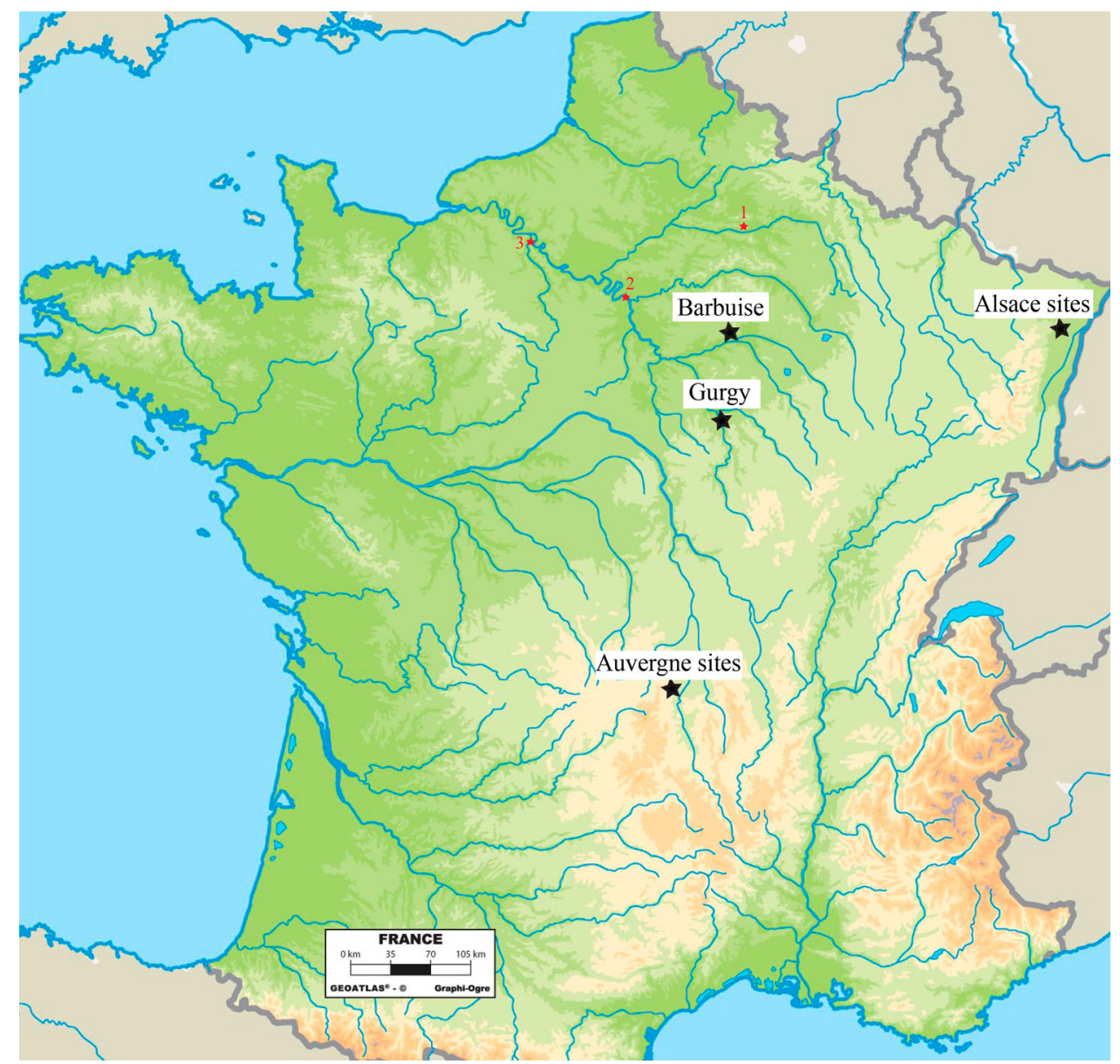

Figure 2. Location of the archaeological sites mentioned in the study. 1 - La Villette (Bocherens et al. 2000); 2 - Bercy and 3 - Maizy/Cuiry (Balasse, 1999, Balasse et al. 2000).

et al. 2009) and does not remodel afterwards. The isotopic ratios recorded in this root thus indicates mean food consumption during these growth years and provides data on an earlier period in life compared to bone (Tables 1 and 2). With this double sampling strategy we expect to detect dietary changes between these two periods of life, particularly for individuals considered as "non-local".

Collagen extraction and apatite purification were performed at the LAMPEA laboratory (UMR 7269, Aix-en-Provence, France). Bone and tooth collagen extraction follow the methods elaborated by Longin (1971) and Bocherens (1992). Material was first cleaned with a sandblaster and ground $(0.7 \mathrm{~mm})$. Bone and root powder were demineralised in a strong acid solution $(\mathrm{HCl} ; 20 \mathrm{~min}$, room temperature), filtered and the remaining residue was put in a $\mathrm{NaOH}$ solution (for $20 \mathrm{~h}$, at room temperature), and filtered again. The remaining residue was solubilised in a

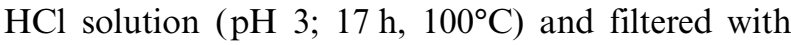
an Ezee-Filter ${ }^{\circledR}$ device. The clean solubilised collagen was frozen, freeze-dried (min $48 \mathrm{~h}$ ) and then analysed by EA-IRMS (Europa Scientific 20-20 IRMS, IsoAnalytical Ltd, UK) with reproducibility below $0 \cdot 1 \%$ for $\mathrm{C}$ and $\mathrm{N}$ stable isotope ratios. LBA bone and root apatite were purified following protocols commonly used for archaeological material (Balasse et al. 2002; Silence and LeGeros 1991). The clean material was more finely ground than for collagen. The powder was put in a sodium hypochlorite solution (24 h, room temperature) and rinsed several times by centrifugation. The remaining residue was left in an acetic acid solution ( $1 \mathrm{~h}$, room temperature) and rinsed several times by centrifugation. The remaining residue was frozen, freeze-dried $(\min 2 \mathrm{~h}$ ) and the carbonate was then analysed using a Kiel IV Carbonate Device coupled to DeltaV Advantage IRMS (SSMIM Muséum National d'Histoire Naturelle, UMR 7209, Paris, France) with a measurement error of $0.03 \%$ for C. Collagen extraction yield, elemental content, stable isotope ratio, $\mathrm{C} / \mathrm{N}$ ratio as well as information on surplus $\mathrm{CaCO}_{3}$ measured on LBA samples are available in Tables 1 and 2.

To compare the isotopic ratios of the different datasets, only non-parametric exact tests were applied (Mann-Whitney U exact test; two-sided test, 0.05 threshold; Statistica 9.1®). This version of non-parametric test is particularly recommended for very small sample size. Moreover, to solve problems linked to multiple comparisons, we applied False 
Table 1 Anthropological, archaeological and stable isotope data of the LBA bone samples from Barbuise

\begin{tabular}{|c|c|c|c|c|c|c|c|c|c|c|c|c|c|c|c|}
\hline Lab code & Species & Sex & Origin & $\% \mathrm{~N}$ & $\% \mathrm{C}$ & $\mathrm{C} / \mathrm{N}$ & Yield (mg/g) & $\delta^{15} \mathrm{~N}_{\mathrm{AIR}(\%)}$ & $\Delta \Delta^{15} \mathrm{~N}_{\mathrm{b}-\mathrm{t}}$ & $\delta^{13} C_{\text {V-PDB }}(\%)$ & $\Delta^{13} \mathrm{C}_{\mathrm{b}-\mathrm{t}}$ & $\mathrm{CaCO}_{3}$ exc. & $\delta^{13} \mathrm{Cap}_{\text {V-PDB }}(\%)$ & $\Delta^{13} \mathrm{Cap}_{\mathrm{b}-\mathrm{t}}$ & $\%$ C4 diet \\
\hline GDF 14440 & Human & $M$ & Non local & & & & $2 \cdot 3$ & & & & & $x$ & $-10 \cdot 8$ & & \\
\hline GDF 14450 & Human & $\mathrm{F}$ & Local & $14 \cdot 4$ & 40.7 & 3.3 & 41.3 & 11.5 & 0.7 & $-19 \cdot 1$ & 0.5 & $x$ & -10.5 & & \\
\hline GDF 1455 o & Human & M & Non local & 14.6 & 39.5 & 3.1 & 31.7 & $10 \cdot 1$ & -1.8 & -19.0 & 0.3 & & $-12 \cdot 3$ & $-1 \cdot 1$ & $22 \cdot 3$ \\
\hline GDF 1293 o & Human & $\mathrm{F}$ & Local & 14.2 & $40 \cdot 1$ & $3 \cdot 3$ & $24 \cdot 2$ & $9 \cdot 8$ & -0.5 & -18.8 & 0.6 & & -10.5 & -0.2 & 35.7 \\
\hline BPV 9338 A o & Human & $M$ & Local & 1.9 & 7.3 & 4.4 & $22 \cdot 8$ & 8.9 & & -22.2 & & $x$ & -11.7 & & \\
\hline BPV 9338 B o & Human & $\mathrm{F}$ & Local & 11.7 & 32.4 & 3.2 & 12.6 & $9 \cdot 3$ & -0.3 & -18.4 & $-1 \cdot 1$ & $x$ & $-10 \cdot 1$ & & \\
\hline BPV $9391 \mathrm{~A} 0$ & Human & $\mathrm{F}$ & Local & 11.9 & 32.4 & 3.2 & 63.3 & 9.3 & -2.4 & -18.9 & 0.3 & $\hat{x}$ & -11.6 & & \\
\hline LBB 951420 & Human & $F$ & Local & & & & 3.7 & & & & & $x$ & $-10 \cdot 7$ & & \\
\hline GDF $9113 f$ & Pig & & & $14 \cdot 3$ & 39.9 & 3.2 & $25 \cdot 1$ & $6 \cdot 6$ & & -19.8 & & $x$ & $-11 \cdot 1$ & & \\
\hline BPV $934727 f$ & Pig & & & & & & 2.4 & & & & & $x$ & -11.3 & & \\
\hline BPV $9113 f$ & Horse & & & $13 \cdot 3$ & 36.9 & 3.2 & $21 \cdot 3$ & $6 \cdot 1$ & & $-21 \cdot 7$ & & & -11.3 & & \\
\hline GDF $94101 \mathrm{f}$ & Horse & & & $15 \cdot 0$ & 44.4 & 3.4 & 25.6 & $7 \cdot 2$ & & $-22 \cdot 3$ & & $x$ & -11.8 & & \\
\hline BPV $94101 \mathrm{f}$ & Dog & & & 11.1 & 31.1 & 3.3 & 37.6 & $7 \cdot 7$ & & $-19 \cdot 0$ & & $\hat{x}$ & $-10 \cdot 1$ & & \\
\hline
\end{tabular}

Percentage of $\mathrm{C}_{4}$ resources in total diet was estimated according to the calculation of Schwarcz (1991) and Ambrose et al. (1997; 2003). Data in italic were not used for the discussion.

Table 2 Anthropological, archaeological and stable isotope data of the Late Bronze tooth samples from Barbuise

\begin{tabular}{|c|c|c|c|c|c|c|c|c|c|c|c|c|c|c|c|}
\hline Lab code & Species & Sex & Origin & $\% \mathrm{~N}$ & $\% \mathrm{C}$ & $\mathrm{C} / \mathrm{N}$ & Yield (mg/g) & $\delta^{15} \mathrm{~N}_{\mathrm{AIR}(\%)}$ & $\Delta^{15} \mathrm{~N}_{\mathrm{b}-\mathrm{t}}$ & $\delta^{13} \mathrm{C}_{\mathrm{V}-\mathrm{PDB}}(\%)$ & $\Delta^{13} \mathrm{C}_{\mathrm{b}-\mathrm{t}}$ & $\mathrm{CaCO}_{3}$ exc. & $\delta^{13}$ Cap V-PDB (\%) & $\Delta^{13} \mathrm{Cap}_{\mathrm{b}-\mathrm{t}}$ & $\%$ C4 diet \\
\hline GDF $1444 d$ & Human & $M$ & & & & & $5 \cdot 2$ & & & & & $x$ & -11.0 & & \\
\hline GDF $1445 d$ & Human & $\mathrm{F}$ & & 13.5 & 37.9 & 3.2 & 39.0 & $10 \cdot 8$ & & $-19 \cdot 7$ & & & $-10 \cdot 4$ & & 33.7 \\
\hline GDF 1455 d & Human & M & & $10 \cdot 2$ & 27.6 & 3.1 & $110 \cdot 1$ & 11.8 & & -19.3 & & & $-11 \cdot 2$ & & 29.7 \\
\hline GDF $1293 d$ & Human & $\mathrm{F}$ & & 14.6 & 39.1 & 3.1 & 87.2 & $10 \cdot 3$ & & -19.4 & & & $-10 \cdot 2$ & & 34.2 \\
\hline BPV 9338 A d & Human & M & & 13.9 & 37.3 & $3 \cdot 1$ & $60 \cdot 6$ & $9 \cdot 2$ & & -19.6 & & $x$ & $-12 \cdot 0$ & & \\
\hline BPV $9338 \mathrm{~B} \mathrm{~d}$ & Human & $\mathrm{F}$ & & $10 \cdot 2$ & $28 \cdot 3$ & 3.2 & 20.4 & 9.6 & & $-17 \cdot 3$ & & $x$ & -11.0 & & \\
\hline BPV $9391 \mathrm{~A} \mathrm{~d}$ & Human & $\mathrm{F}$ & & 14.1 & 39.0 & 3.2 & $165 \cdot 3$ & $11 \cdot 7$ & & $-19 \cdot 2$ & & & $-10 \cdot 6$ & & $26 \cdot 7$ \\
\hline LBB 95142 d & Human & $\mathrm{F}$ & & 14.9 & $40 \cdot 6$ & 3.2 & $75 \cdot 8$ & 9.4 & & $-18 \cdot 2$ & & & $-10 \cdot 2$ & & 33.0 \\
\hline
\end{tabular}

Percentage of $C_{4}$ resources in total diet was estimated according to the calculation of Schwarcz (1991) and Ambrose et al. (1997; 2003). Data in italic were not used for the discussion. 


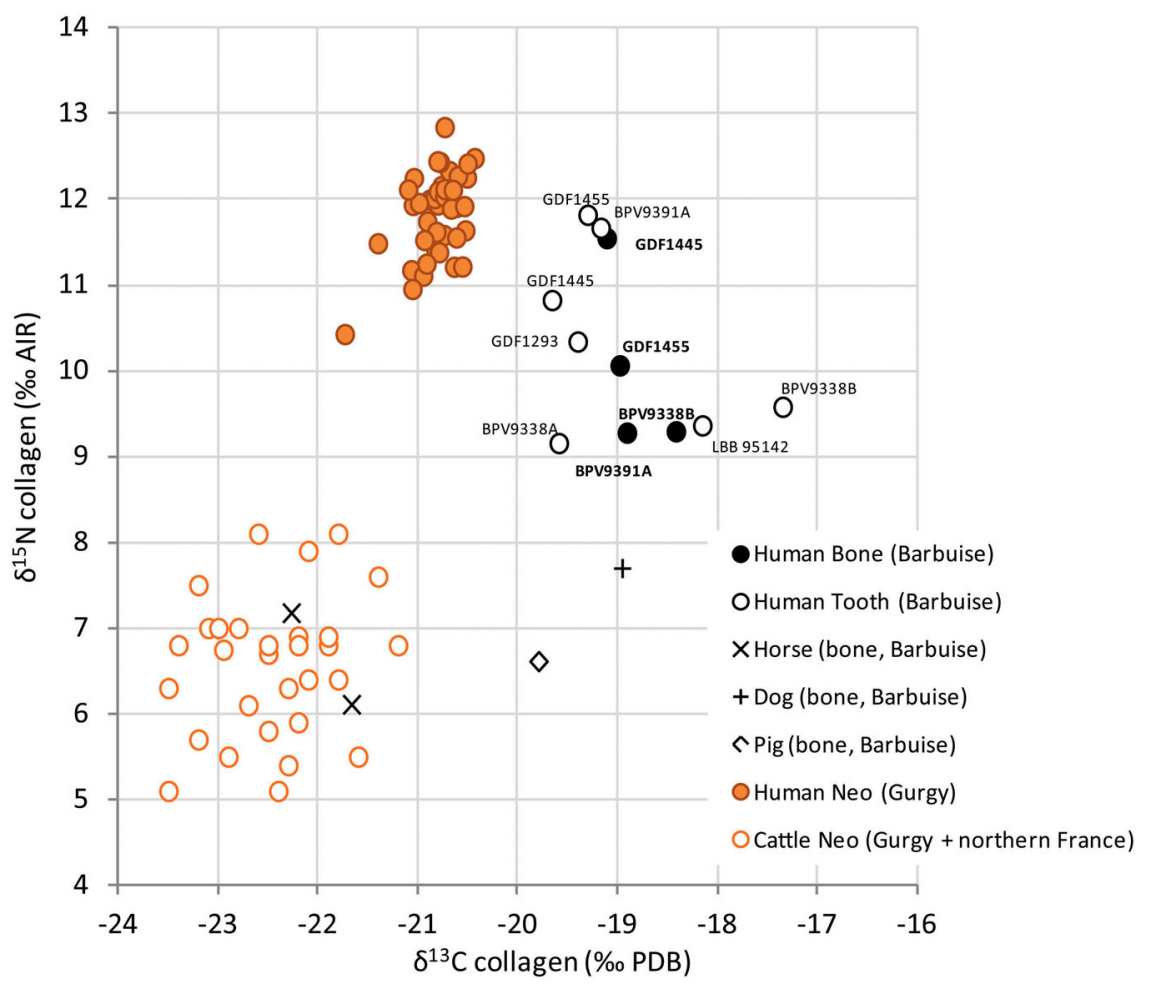

Figure 3. C and N stable isotope ratios of human and animal bones/teeth from Barbuise (this study), Gurgy (Rey 2013) and other northern sites (Balasse 1999; Balasse et al. 1997).

Discovery Rate correction (FDR; Benjamini and Hochberg 1995; Benjamini and Yekutieli 2001; $\mathrm{R}$ Core Team 2016) to $p$-values obtained for pairwise comparisons.

\section{Results and discussion}

\section{The $L B A$ diet}

The collagen quality was checked according to several criteria and particularly the $\mathrm{C} / \mathrm{N}$ ratio (Ambrose 1990; DeNiro 1985). Among the 21 LBA samples, four had a very low collagen extraction yield $(<10 \mathrm{mg} / \mathrm{g})$ and were not analysed; one sample gave poor $\% \mathrm{C}, \% \mathrm{~N}$ and $\mathrm{C} / \mathrm{N}$ results and was excluded from our corpus (in italics in Tables 1 and 2; Ambrose 1990; DeNiro 1985; van Klinken 1999). The data set is thus composed of seven teeth, five human and four animal bone collagen samples. The preservation of the apatite carbonate is difficult to assess, in particular for human bone and dentin samples. Infrared analyses (FTIR) were attempted, most of the time using the crystallinity index $(\mathrm{CI}$; e.g., Weiner et al. 1993). However, although FTIR gives promising results to detect well vs. poorly preserved bone structures (Lebon et al. 2010, 2011; Salesse et al. 2014), the correlation with the preservation of the in vivo stable isotope ratio has not been demonstrated to date (e.g., Beasley et al. 2014; Hu et al. 2008; Salesse et al. 2014). All the 21 LBA bone and dentin carbonate apatite gave isotopic results, but several samples displayed carbonate surpluses during IRMS analysis. This surplus can be considered as potentially contaminating (Zazzo 2001). Our interpretation is thus only based on the rest of the available samples: five human teeth, two human bones and one animal bone. Moreover, we can observe that samples with a low collagen yield all have carbonate surpluses (Tables 1 and 2). These observations are consistent with the study by $\mathrm{Hu}$ et al. (2006), in which apatite is considered to be more degraded when collagen is poorly preserved.

LBA animal ratios range from $-22.3 \%$ to $-19.0 \%$ o for carbon and from $6 \cdot 1 \%$ to $7 \cdot 7 \%$ or nitrogen $(n=$ 4). LBA animals from Barbuise show different isotopic ratios according to the species. Pig and dog, both omnivorous animals, have higher $\delta^{13} \mathrm{C}$ compared to horses (comparison cannot be statistically tested due to the very small sample size). On the other hand, $\delta^{15} \mathrm{~N}$ is similar for the three species. Equids from Barbuise show similar $\delta^{13} \mathrm{C}$ to Neolithic herbivores $(n=33)$ from northern France $(P<0.05$; Fig. 3). The horse diet is made up of grass but they can also be fed with hay, straw or grain, and in any case with open environment resources (e.g. King and Gurnell 2005; Mihlbachler et al. 2011). Taking into account their ethology and their isotopic similarities with Neolithic domestic species (Balasse 1999; Balasse et al. 1997, 2000; Bocherens et al. 2000), it is relevant to assume that horse isotopic ratios provide a baseline for LBA $\mathrm{C}_{3}$ plant consumers in this region. At Barbuise, the difference between pig/dog and horses 
$\delta^{13} \mathrm{C}$ ranges from $2 \cdot 2 \%$ to $3 \cdot 0 \%$, implying that $\mathrm{pig} / \mathrm{dog}$ analysed consumed ${ }^{13} \mathrm{C}$ enriched food compared to horses. The intake of animal protein in the diet of pig/dog does not seem a relevant hypothesis to explain this difference, as pig and horses show identical $\delta^{15} \mathrm{~N}$ and the $\delta^{15} \mathrm{~N}$ difference between dog and horses is only $1.0 \%$. Considering the region and the period, the only ${ }^{13} \mathrm{C}$ enriched food is a $\mathrm{C}_{4}$ plant: millet; local/regional comparisons will further support this hypothesis (cf. $\S$ Diachronic comparisons).

LBA human collagen isotopic ratios range from $-19.7 \%$ to $-17 \cdot 3 \%$ for carbon and from $9.2 \%$ to $11.8 \%$ or nitrogen $(n=12$; Tables 1 and 2). LBA bone and tooth apatite $\delta^{13} \mathrm{C}$ ratios range from $-12 \cdot 3 \%$ to $-10 \cdot 2 \%$ o $(n=8$; Tables 1 and 2$)$. Combined with collagen data, the carbon isotopic ratio in apatite has often been used to assess the trophic level of animals (Ambrose et al. 2003; Hedges 2003; Lee-Thorp et al. 1989), and to estimate the contribution of marine vs. terrestrial or $\mathrm{C}_{3} v s . \mathrm{C}_{4}$ food in the whole human diet (Ambrose et al. 1997, 2003; Froehle et al. 2012; Kellner and Schoeninger 2007; Schwarcz 1991). The apatite-collagen spacing model $\left(\Delta^{13} \mathrm{C}_{\mathrm{ap}}\right.$-coll $)$ helps to estimate the relative proportion between $\mathrm{C}_{3} / \mathrm{C}_{4}$ protein vs. $\mathrm{C}_{3} / \mathrm{C}_{4}$ lowprotein food; a $\Delta^{13} \mathrm{C}_{\mathrm{ap}}$-coll greater than $4.4 \%$ o demonstrates a protein intake depleted in ${ }^{13} \mathrm{C}$ compared to the overall diet (Ambrose et al. 2003). Using the Schwarcz (1991) and Ambrose et al. (1997; 2003) equation, we proposed a percentage of $\mathrm{C}_{4}$ plant in the overall diet of each individual of Barbuise: \% $\mathrm{C}_{4}=\left(-25-\left(\delta^{13} \mathrm{C}_{\mathrm{ap}}-9.4\right)\right) / 15^{*} 100$ (Tables 1 and 2). Estimations range from ca. $22 \%$ to $36 \%$. According to the authors (ibid.), at least $20 \%$ of $\mathrm{C}_{4}$ food in the diet is required in order to be detected in the collagen isotopic signature. Our apatite data are just over this limit which partially justifies the low human $\delta^{13} \mathrm{C}_{\text {coll }}$ compared to other populations for which diet is mainly based on $\mathrm{C}_{4}$ plants (Tafuri et al. 2009). The application of the Kellner and Schoeninger regression lines (2007) and the combination of collagen $\delta^{15} \mathrm{~N}$ with $\Delta^{13} \mathrm{C}_{\mathrm{ap}}$-coll indicate a major protein intake from a $\mathrm{C}_{3}$ environment (Fig. 4) and a bulk diet including a significant portion of low-protein $\mathrm{C}_{4}$ food (Fig. 5). In this case, the more relevant dietary pattern for LBA humans would be the consumption of $\mathrm{C}_{3}$-feeding animals (possibly horses; cattle and caprines are not analysed in this study) and different cereals with millet.

\section{LBA intra-individual comparison}

Due to poor sample preservation, intra-individual comparisons, specifically for "non-local" subjects, do not conform to our expectations. Only five humans yielded both tooth and bone collagen results and two for apatite. Considering the type of data, intra-individuals, only paired difference test (Wilcoxon) can be performed; however, the limited sample size does not allow using it and no statistical comparison can be made. We thus attempted to understand potential variability between $\mathrm{M} 2$ root dentin (marking mainly childhood) and bone (marking adulthood) looking at the Fig. 6. Discussion in this case is speculative but few observations worth to be pinpointed. The more intriguing individual is the "non-local" GDF 1455, on which an increase of $1.7 \%$ for $\delta^{15} \mathrm{~N}$ and $1.1 \%$ for $\delta^{13} \mathrm{C}_{\mathrm{ap}}$ is observed between childhood and adulthood. The diet of this subject could have changed, with a higher animal protein intake and more $\mathrm{C}_{4}$ plants (or animals fed with $\mathrm{C}_{4}$ plants), during the last years of life. The new diet could be linked to mobility and a new living place as suggested by funerary evidence. The female BPV 9391A shows a $\delta^{15} \mathrm{~N}$ decrease, suggesting a lower animal protein intake during adulthood. This is a shared feature (i.e. dietary modification) with the "non-local" male but no archaeological evidence supports this observation.

\section{Diachronic local comparison}

The necropolis of Les Noisats at Gurgy (also called Gurgy; Yonne, France) is located ca. $76 \mathrm{~km}$ south of Barbuise. Gurgy is the biggest Neolithic site studied and available for a diachronic local comparison with Barbuise, including 128 individuals found in different types of burials (Rottier et al. 2007; Rottier et al. 2005). The necropolis was used and expanded during the 5th millennium BC in an archaeologically welldocumented geographical area (Chambon et al. 2013). Funerary practices are homogeneous and seem to be linked to the location of the site, at the intersection between Danubian and Mediterranean cultural influences (Rivollat et al. 2015). However, the necropolis cannot be exclusively associated with one of the archaeological cultures known in the region (Cerny and Chassey; Chambon et al. 2013). The men, women and children buried in the necropolis do not display distinct anatomical traits and cannot thus be clustered into different groups. Moreover, a first study of dental microanatomy and occlusal tooth wear confirms the apparent homogeneity of these individuals and appears to corroborate the hypothesis of a similar dietary pattern for all of them (Le Luyer et al. 2014; Rey et al. 2013). The long duration of the necropolis (one millennium) and the apparent similarity of the individuals buried there contrast with the archaeological record (diversity of goods and funerary structures) attesting to multiple peripheral contacts. This necropolis could be defined as a "homogeneous mosaic" in which the different cultural influences would have been integrated by a population and then absorbed into their own territory. At Gurgy, stable isotope 


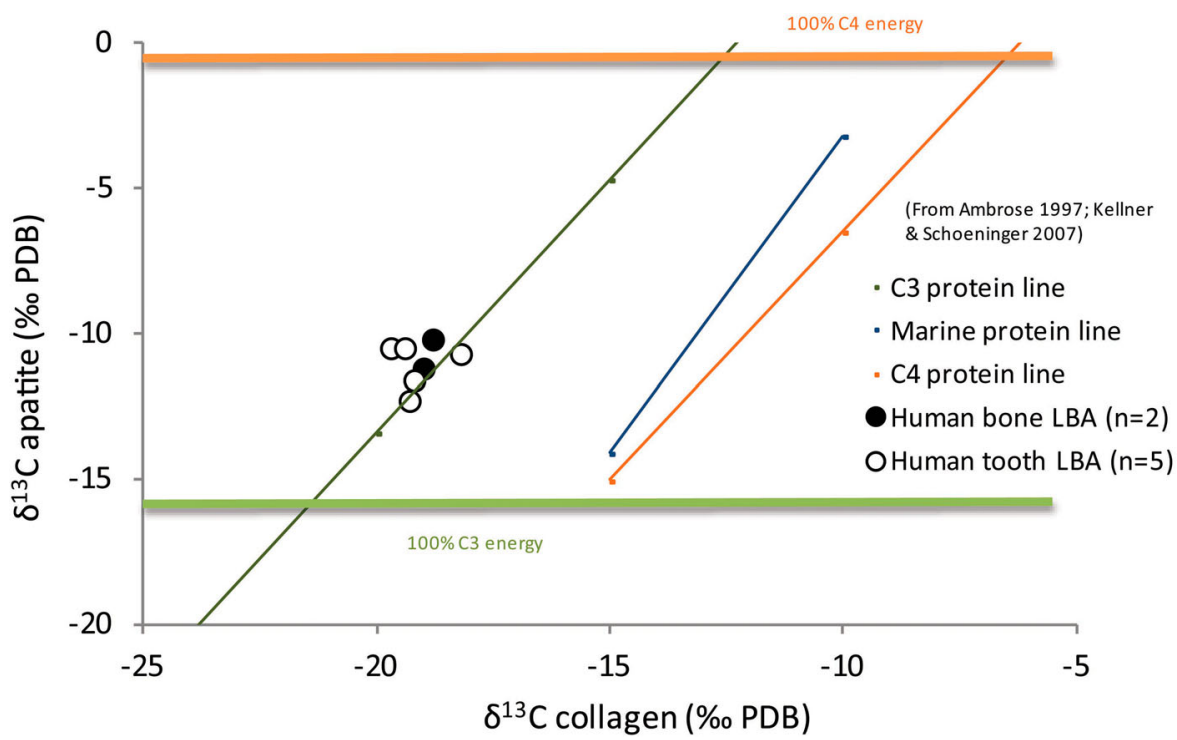

Figure 4. Comparison of $\mathbf{C}$ stable isotope ratios from collagen and apatite from human teeth and bones of Barbuise according to the model of Kellner and Schoeninger (2007).

ratios are available for 40 human bones ( 12 females, 20 males, 5 undetermined $>15$ years old and 3 children between 5 and 14 years old), and one Bos sp. bone (Rey 2013; Rey et al. 2013). Neolithic human collagen isotopic ratios range from $-21 \cdot 1 \%$ to $-20.4 \%$ for carbon and from $10 \cdot 9 \%$ to $12 \cdot 8 \%$ for nitrogen $(n=$ 40; Rey 2013; Rey et al. 2013). The Bos sp. from Gurgy show consistent isotopic ratios $\left(\delta^{13} \mathrm{C}=-23.0 \%\right.$; $\delta^{15} \mathrm{~N}=6.7 \%$ ) with those from domestic herbivores recorded in northern France: from $-23.6 \%$ to $-21.2 \%$ o for carbon and from $5.1 \%$ to $8.1 \%$ for nitrogen (for bovines and caprines, $n=36$; Balasse 1999; Balasse and Tresset 2002; Balasse et al. 1997, 2000; Bocherens et al. 2000; Goude and Fontugne 2016). The study carried out by Rey (2013; Rey et al. 2013) indicate that Neolithic humans had high animal protein intake and/or significant ${ }^{15} \mathrm{~N}$ enriched protein consumption $\left(\Delta^{13} \mathrm{C}_{\text {human-cattle }}\right.$ of ca. $2.0 \%$ and $\Delta{ }^{15} \mathrm{~N}$ human-cattle of ca. $5.0 \%$ ), such as freshwater fish or young domestic herbivores. No archaeozoological evidence from Gurgy site currently preferentially points to one or the other of these hypotheses. Milk exploitation and calf slaughtering is confirmed on the Neolithic sites of Balloy (Tresset 1990), Bercy, Cuiry and Maizy (Fig. 1; Balasse 1999; Balasse and Tresset 2002; Balasse et al. 1997, 2000) and could partly explain the human values registered at Gurgy (consumption of young domestic animals high in the trophic web). However, freshwater fish is also a resource to consider. Freshwater food consumption in the Paris Basin was shown for the Mesolithic by analysing amino acid isotopic ratios of human bone from Noyen-sur-Seine (Naito et al. 2013). Moreover, this hypothesis was also proposed for the

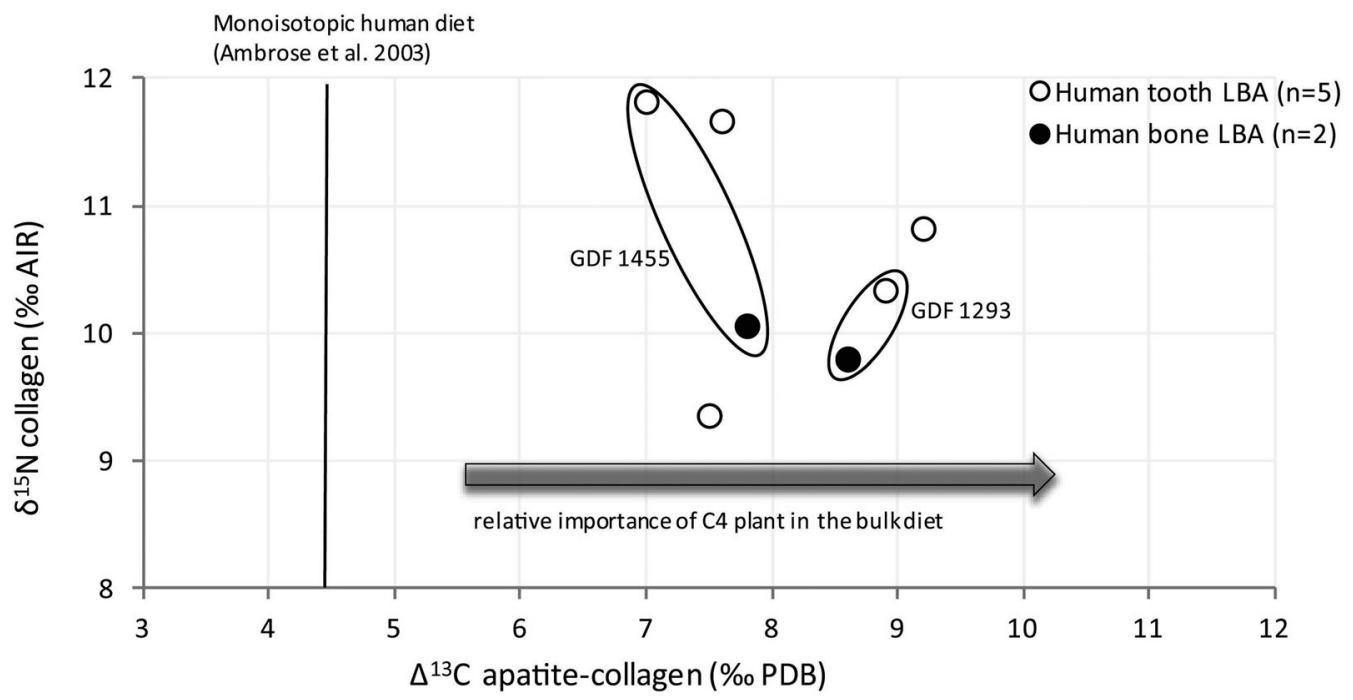

Figure 5. Comparison of $\mathrm{N}$ stable isotope ratios in collagen and $\mathrm{C}$ stable isotope ratios of collagen-apatite spacing human teeth and bones of Barbuise, according to the model of Ambrose et al. (1997; 2003). 

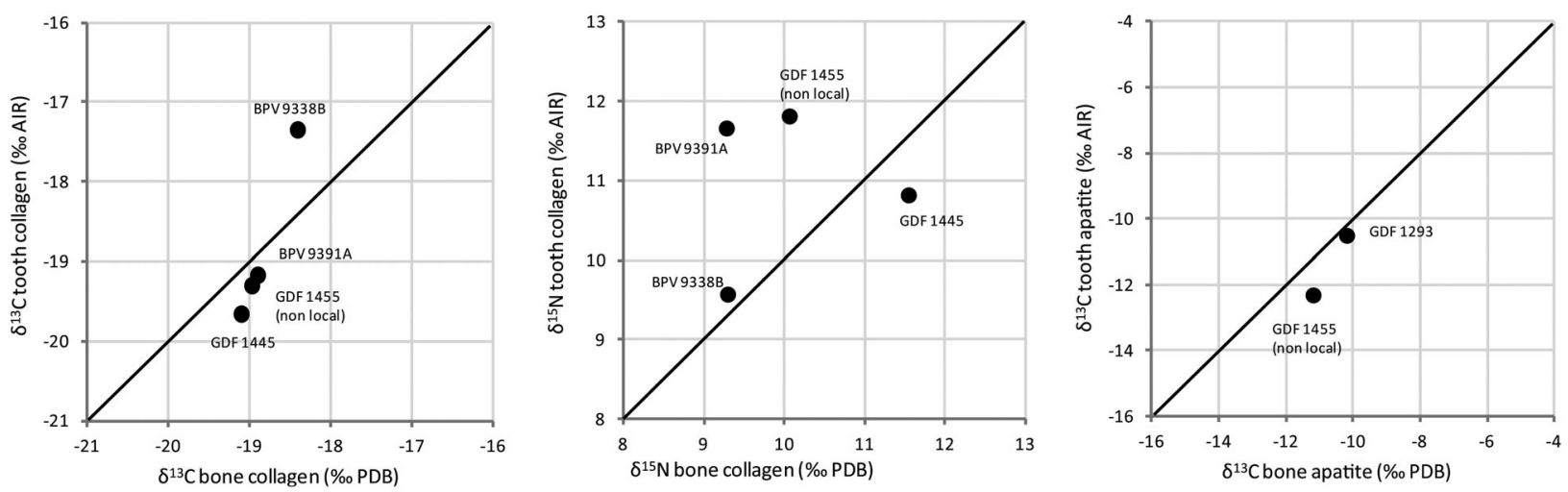

Figure 6. Comparison of stable isotope ratios (collagen and apatite) between bone and teeth for each individual.

contemporaneous human group of Pontcharaud (Auvergne, Fig. 1), where the vicinity of streams allows for the easy acquisition of such food (Goude et al. 2013) and for any Neolithic sites in Germany and Belgium (e.g., Bocherens et al. 2006; Bösl et al. 2006; Dürrwächter et al. 2006). Furthermore, the significant amount of fish remains found in several Villeneuve-Saint-Germain (a nearby Neolithic culture) sites in the Paris Basin, and the seasonal catch, indicate that fishing could have provided a significant source of protein during the warm period, in addition to farm produce (Clavel 2009; Clavel and Arbogast 2007). LBA human isotopic ratios are statistically different from Neolithic ratios for both $\mathrm{C}$ and $\mathrm{N}$ $(P<0.01)$. LBA human bone collagen show higher $\delta^{13} \mathrm{C}(\mu=-18.8 \%, 0.3 \mathrm{SD} ; n=5)$ and lower $\delta^{15} \mathrm{~N}$ $(\mu=10.0 \%, 0.9 \mathrm{SD})$ than Neolithic ones, distinctly visible in Fig. 3. In the same way as for animals, LBA human protein intake seems to include a significant part of ${ }^{13} \mathrm{C}$ enriched food, such as millet grain and/or animals fed with millet (as is the case for the pig from Barbuise).The isotopic data set leads us to propose the following first diachronic scheme in this region: a mixed Neolithic human diet with a significant amount of terrestrial animal protein and probably freshwater resources and a mixed LBA human diet with less animal protein intake and increased cereal consumption, including $\mathrm{C}_{4}$ plants.

\section{Diachronic regional comparison}

Additionally to Gurgy, several Neolithic to Iron Age sites have been recently investigated by stable isotope analysis in the northern half of France and hold our attention for regional comparisons (Goude et al. 2013; Herrscher et al. 2013; Le Bras-Goude et al. 2011). This area focused our interest due to the availability of human/animal remains and to the presence of millet archaeological charred seeds indicating that $\mathrm{C}_{4}$ plant commonly circulated from East at the end of Prehistory (e.g., Cabanis et al. 2010; FerrageToulemonde 2013). Although we identified few millet eaters during the Iron Age (IA) in Alsace
(Goude et al. 2014), Barbuise is, for the moment, the only LBA site in this area where human/animal remains were enough preserved and where local archeobotanical study was well detailed to document the both cultivation and consumption of this new cereal at its arrival. Thus, the comparison between Barbuise and other Protohistoric sites, located in the area of the spread of millet, appeared obvious to understand the possible dietary changes implied by this new crop. Barbuise isotopic data were compared with different regional sites (Fig. 2): Auvergne (Middle Neolithic and EBA) and the Alsace region (Late Neolithic and IA; Goude et al. 2013, 2014 Herrscher et al. 2013; Le Bras-Goude et al. 2011), as well as the Neolithic sites of Bercy (4th mill. cal. BC; Balasse et al. 1997), La Villette (4th mill. cal. BC; Giligny 2005) and Cuiry/Maizy (Balasse 1999; Balasse et al. 2000; Bocherens et al. 2000) for animals (Fig. 7). As the geographical location of sites can lead to environmental isotopic variations in plants (e.g., Amundson et al. 2013; Goude and Fontugne 2016; Tieszen and Boutton 1989), domestic animals are thus first compared. Neolithic cattle from northern France, Alsace and Auvergne regions show the lowest $\delta^{13} \mathrm{C}$ ratios (from $-23.5 \%$ to $-21 \cdot 2 \%, n$ $=39$ ). IA and EBA cattle have $\delta^{13} \mathrm{C}$ ratios within a similar range $(-21.4 \%$ to $-20.8 \%, n=6)$ as the LBA horses; these values can be considered as a local range base for $\mathrm{C}_{3}$ herbivores in the demarcated area. Neolithic, EBA and IA pigs from northern France, Auvergne and Alsace have similar $\delta^{13} \mathrm{C}$ ratios: from $-21.0 \%$ to $-20 \cdot 1 \%$ o $(n=16)$; the LBA pig data are slightly higher $(-19 \cdot 8 \%)$. One of the most striking results concerns dogs (Fig. 7). Neolithic and EBA dogs have lower $\delta^{13} \mathrm{C}$ ratios $(21.0 \%$ to $-20.0 \%, n=5)$ than the LBA Barbuise $\operatorname{dog}(-19.0 \%)$. Neolithic dogs show the highest $\delta^{15} \mathrm{~N}$ ratios (from $9.1 \%$ o to $10.0 \%$ ) compared to the LBA $(7.7 \% 0)$ and EBA ones $(7.6 \%$ and $8.7 \%)$. The higher carbon isotopic Barbuise pig and dog ratios, as well as the low $\delta^{15} \mathrm{~N}$ dog ratio, can be fairly well linked to the consumption of human food or refuse, including 


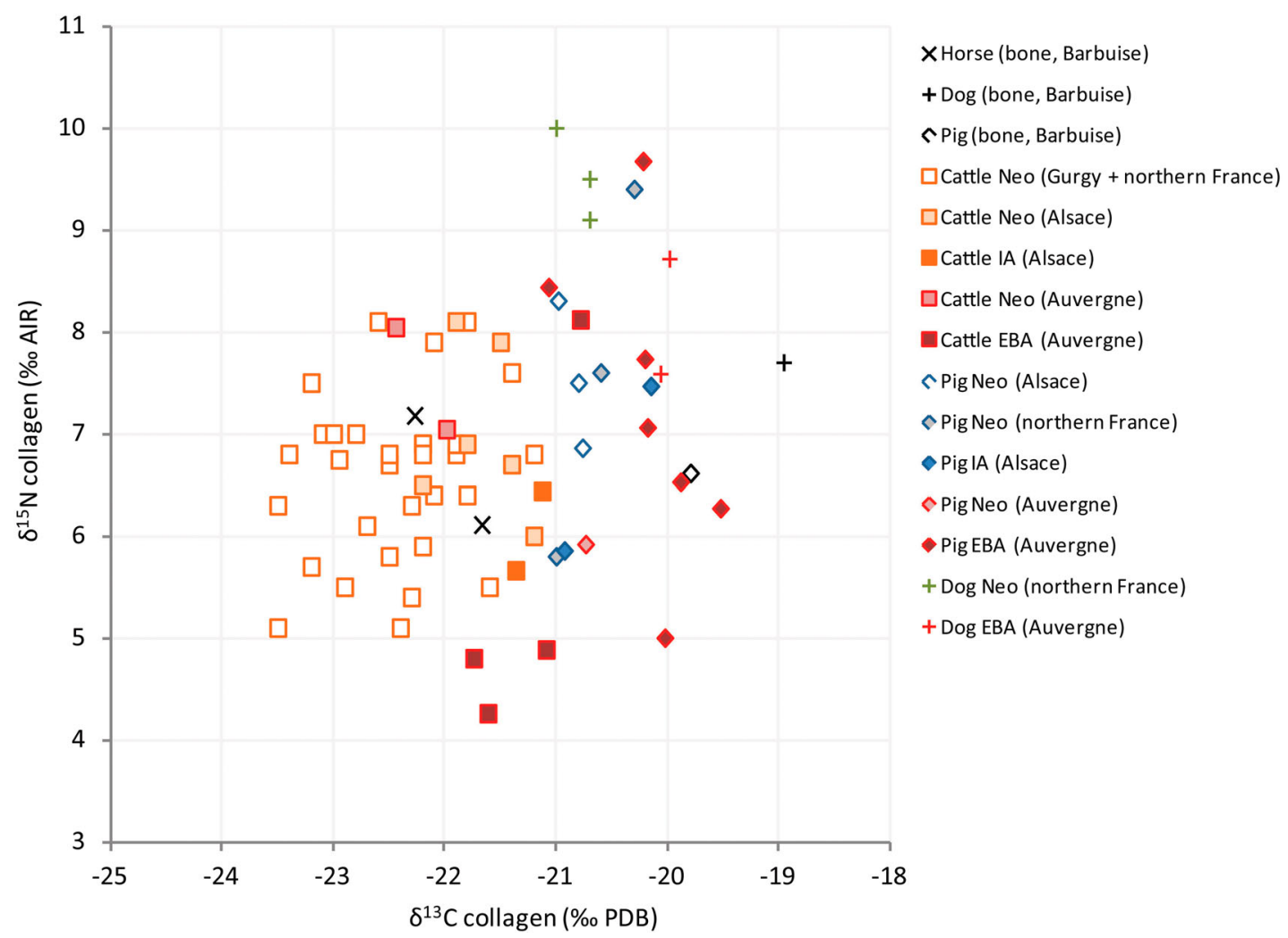

Figure 7. C and N stable isotope ratios of animal bones Barbuise (this study), Gurgy (Rey 2013) and other Neolithic, Early Bronze Age (EBA) and Iron Age (IA) sites in northern France (Balasse 1999; Balasse et al. 1997; Goude et al. 2014).

a certain amount of ${ }^{13} \mathrm{C}$ enriched protein, such as millet and/or animals fed with millet. A diachronic comparison of the human data is presented in Fig. 8 (immature > three-year-old and adults). Neolithic individuals from Gurgy and Late Neolithic (LN) specimens from the Alsace region display isotopic ratios ranging from $-21.7 \%$ to $-19.5 \%$ for carbon and from $9 \cdot 7 \%$ to $13 \cdot 2 \%$ for nitrogen $(n=76)$. In the Centre of France, the isotopic range for Middle Neolithic and EBA individuals varies from $-20.9 \%$ to $-19.2 \%$ for carbon and from $8.6 \%$ to $13.0 \%$ for nitrogen $(n=107)$. IA specimens from Alsace $\left(\delta^{13} \mathrm{C}\right.$ : $-20.5 \%$ to $-20.0 \%$; $\delta^{15} \mathrm{~N}$ : $7.8 \%$ o to $\left.10.5 \%, n=4\right)$ differ statistically from Neolithic individuals from the same site $(P<0.05$; Goude et al. 2014; Fig. 8). These differences, with lower $\delta^{15} \mathrm{~N}$ and higher $\delta^{13} \mathrm{C}$, have been described either as a climatic difference between the two periods or as a shift to a diet with less animal protein and a higher cereal intake, including millet, for IA humans (Goude et al. 2014). The presence of few millet archaeobotanical remains in Alsace and the lack of archaeological and environmental data pointing towards significant climatic change tend to back up the second hypothesis. This pattern is similar when comparing LBA humans from Barbuise and Neolithic subjects from Gurgy. A statistical comparison between Barbuise humans (bone collagen) and the other Neolithic sites located in the northern and centre of France highlights significant isotopic differences, particularly for carbon (Alsace-Neolithic vs. LBA: $P<0.01$ for $\delta^{13} \mathrm{C}$ and $P<0.05$ for $\delta^{15} \mathrm{~N}$; Auvergne-Neolithic vs. LBA: $P<0.01$ only for $\delta^{13} \mathrm{C}$ ). Similar results emerge from the comparison of EBA humans from Auvergne $\left(P<0.01\right.$ only for $\left.\delta^{13} \mathrm{C}\right)$ and also for IA individuals from Alsace with LBA human bone data from Barbuise $\left(P<0.05\right.$ for both $\delta^{13} \mathrm{C}$ and $\left.\delta^{15} \mathrm{~N}\right)$. Even though the carbon isotopic ratios recorded at Barbuise are lower than more commonly recorded data in other millet eaters (e.g., Tafuri et al. 2009, Varalli et al. 2014), the diachronic and local comparisons of bone collagen results strongly support dietary change during the LBA period, probably linked to increases in millet crops (Jacob et al. 2008). By Looking at the few EBA sites already studied in France (Herrscher, in press; Herrscher et al. 2013), stable isotope data do not demonstrate that $\mathrm{C}_{4}$ plant was included in the daily diet. The same assessment was also proposed in Italy (Varalli, 2015). However, in Italy, the recent studies performed on North, Centre and Liguria, have demonstrated a significant impact of $\mathrm{C}_{4}$ plants in protein intake at the EarlyMiddle Bronze Age transition (Tafuri et al. 2009; Varalli et al. 2013, 2016). For these areas, $C_{4}$ plants/ animal fed with $\mathrm{C}_{4}$ plants became important food sources, particularly at the LBA-IA transition (Varalli et al. 2012-2013). This contrast reflects either an heterogeneous diffusion of millet crop 


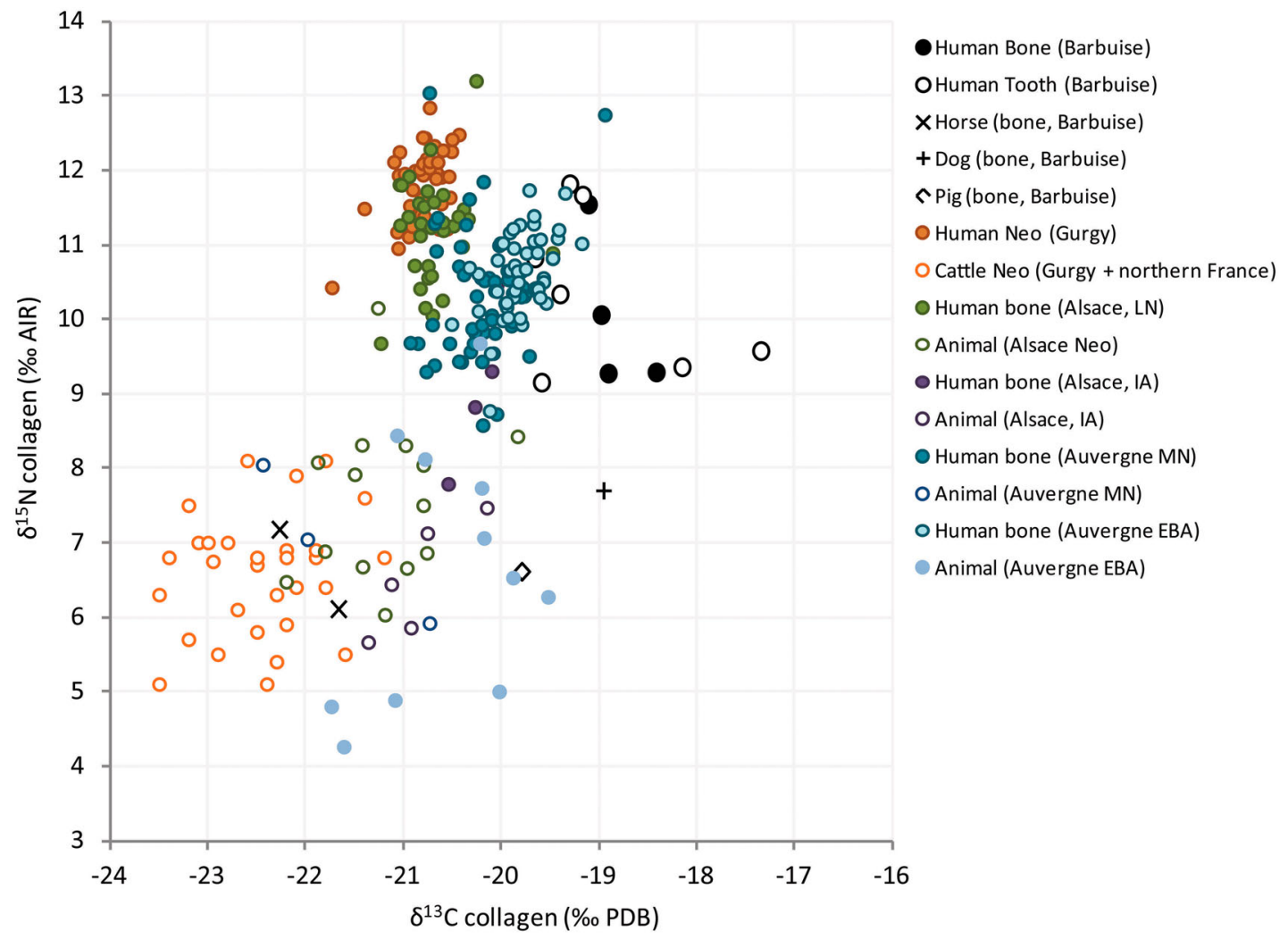

Figure 8. Human and animal $\mathbf{C}$ and $\mathbf{N}$ stable isotope ratios from Neolithic to Iron Age in northern and Centre of France (this study, Balasse 1999; Goude et al. 2014; Herrscher et al. 2013; Rey 2013). LN: Late Neolithic; IA: Iron Age; MN: Middle Neolithic; EBA: Early Bronze Age.

through France and less impact of such plant in diet and/or a crucial lack of Bronze Age and IA isotopic data in French regions concerned by its diffusion.

\section{Conclusion}

Diachronic comparisons of human and animal stable isotope ratios, as well as archaeobotanical studies performed in the Paris Basin and surrounding areas, support the archaeological hypothesis on dietary and food economy changes since the LBA. For the first time in France, this study highlights millet consumption by LBA humans (14th c. BC) using stable isotope analysis and illustrates the importance of local comparisons for detecting dietary modifications. Broomcorn millet may have spread from Asia to Europe during the Bronze Age (earliest findings in Europe and Caucasus, some of which are listed in Hunt et al. 2008, are currently under revision by AMS radiocarbon dating and the first results did not yield dates prior to 1606-1414 cal BC; Hajnalova et al. 2013; Motuzaite-Matuzeviciute et al. 2013). The diffusion of millet as a crop occurred at different rates (Lightfoot et al. 2013; Motuzaite-Matuzeviciute et al. 2015; Stevens et al. 2012). It is widely accepted that millet was extensively cultivated during the LBA in the Paris Basin but we still do not know exactly when it was introduced and became an established crop. Settlement sites are very scarce in the area for the Early and Middle Bronze Ages, and archaeobotanical data are even more scant. Considering the lack of archaeobotanical data for these periods (only a few settlements), it is now essential to conduct new isotopic studies on Early/Middle Bronze Age human and animal remains to record the advent of millet in the region and its role in diet.

\section{Acknowledgements}

This work was funded by the Agence Nationale de la Recherche - Investissements d'avenir - ANR-10LABX-52 (LaScArBx, projet DHP) and the University of Bordeaux. Archaeobotanical studies received a grant from the Direction de l'Architecture et du Patrimoine from the Ministry for Culture and Communication. We also thank S. Cabut for the statistical expertise (UMR 7269 LAMPEA, Aix en Provence, France) and J. Ughetto and M. Balasse (SSIMM MNHN UMR 7209, Paris, France) for their availability and services.

\section{References}

Ambrose, S. H. 1990. Preparation and characterization of bone and tooth collagen for isotopic analysis. Journal of Archaeological Science 17, 431-51.

Ambrose, S. H. and De Niro, M. J. 1989. Climate and habitat reconstruction using stable Carbon and Nitrogen isotope ratios of collagen in prehistoric herbivore teeth from Kenya. Quaternary Research 31, 407-22. 
Ambrose, S. H. and Norr, L. 1993. Experimental evidence for the relationship of the carbon isotope ratios of whole diet and dietary protein to those of bone collagen and carbonate, pp. 1-37 in Lambert, J. B., Grupe, G. (eds.), Prehistoric Human Bone Archaeology at the Molecular Level. Berlin: SpringerVerlag.

Ambrose, S. H., Buikstra, J. and Krueger, H. W. 2003. Status and gender differences in diet at Mound 72 Cahokia revealed by isotopic analysis of bone. Journal of Anthropological Archaeology 22, 217-26.

Ambrose, S. H., Butler, B. M., Hanson, D. B., Hunter-Anderson, R. L. and Krueger, H. W. 1997. Stable isotopic analysis of human diet in the Marianas archipelago, Western Pacific. American Journal of Physical Anthropology 104, 343-61

Amundson, R., Austin, A. T., Schuur, E. A. G., Yoo, K., Matzek, V., Kendall, C., Uebersax, A., Brenner, D. and Baisden, W. T. 2013. Global patterns of the isotopic composition of soil and plant nitrogen. Global Biogeochemical Cycles 17, 1031.

Balasse, M. 1999. De l'exploitation du lait au Néolithique moyen en Europe tempérée. Examen des modalités de sevrage des bovins par l'analyse isotopique des ossements archéologiques. Unpublished $\mathrm{PhD}$ dissertation, Université Paris VI.

Balasse, M., Ambrose, S. H., Smith, A. B. and Price, T. D. 2002. The seasonal mobility model for prehistoric herders in the Southwestern Cape of South Africa assessed by isotopic analysis of sheep tooth enamel. Journal of Archaeological Science 29, 917-32.

Balasse, M., Bocherens, H., Tresset, A., Mariotti, A. and Vigne, J.D. 1997. Emergence de la production laitière au NéolithiqueContribution de l'analyse isotopique d'ossements de bovins archéologiques. Comptes rendus de l'Académie des sciences Série 2, Sciences de la terre et des planètes 325, $105-1010$.

Balasse, M. and Tresset, A. 2002. Early weaning of neolithic domestic cattle (Bercy, France) revealed by intra-tooth variation in nitrogen isotope ratios. Journal of Archaeological Science 29, 853-9.

Balasse, M., Tresset, A., Bocherens, H., Mariotti, A. and Vigne, J.D. 2000. Un abattage "post-lactation" sur des bovins domestiques néolithiques. Etude isotopique des restes osseux du site de Bercy (Paris, France). Ibex Journal of Mountain Ecology/ Anthropozoologica 5, 39-48.

Beasley, M. M., Bartelink, E. J., Taylor, L. and Miller, R. M. 2014. Comparison of transmission FTIR, ATR, and DRIFT spectra: Implications for assessment of bone bioapatite diagenesis. Journal of Archaeological Science 46, 16-22.

Benjamini, Y. and Hochberg, Y. 1995. Controlling the false discovery rate: a practical and powerful approach to multiple testing. Journal of the Royal Statistical Society, Series B (Methodological) 57, 289-300.

Benjamini, Y. and Yekutieli, D. 2001. The control of the false discovery rate in multiple testing under dependency. The Annals of Statistics 29, 1165-88.

Besse, M. (ed.) 2007. Sociétés Néolithiques: Des faits archéologiques aux fonctionnements socio-économiques. Actes du $27^{e}$ colloque interrégional sur le Néolithique. Neufchâtel: Cahier d'archéologie romande.

Bocherens, H. 1992. Biogéochimie isotopique (13C, 15N, 18O) et paléontologie des vertébrés : application à l'étude des réseaux trophiques révolus et des paléoenvironnements. Unpublished $\mathrm{PhD}$ dissertation, Université Paris VI.

Bocherens, H. and Drucker, D. 2003. Trophic level isotopic enrichment of carbon and nitrogen in bone collagen: case studies from recent and ancient terrestrial ecosystems. International Journal of Osteoarchaeology 13, 46-53.

Bocherens, H., Billiou, D. and Tresset, A. 2000. Approche biogéochimique $(13 \mathrm{C}, 15 \mathrm{~N})$ de l'exploitation de l'environnement par les humains, pp. 265-9 in Giligny, F. (ed.), Louviers "La Villette" (Eure): Un Site Néolithique Moyen en Zone Humide. Rennes: Documents Archaéologiques de l'Ouest.

Bocherens, H., Polet, C. and Toussaint, M. 2006. Palaeodiet of Mesolithic and Neolithic populations of Meuse Basin (Belgium): evidence from stables isotopes. Journal of Archaeological Science 34, 10-27.

Bonsall, C., Cook, G. T., Hedges, R. E. M., Higham, T. F. G., Pickard, C. and Radovanovic, I. 2004. Radiocarbon and stable isotope evidence of dietary change from the mesolithic to the middle ages in the iron gates: new results from Lepenski Vir. Radiocarbon 46, 293-300.
Bonsall, C., Cook, G. T., Lennon, R., Darkness, D., Scott, M., Bartosiewicz, L. and McSweeney, K. 2000. Stable isotopes, radiocarbon and the Mesolithic-Neolithic transition in the iron gates. Documenta praehistorica 27, 119-32.

Boric, D., Grupe, G., Peters, J. and Mikic, Z. 2004. Is the Mesolithic-Neolithic subsistence dichotomy real? New stable isotope evidence from the Danube Gorges. European Journal of Archaeology 7, 221-48.

Bösl, C., Grupe, G. and Peters, J. 2006. A late Neolithic vertebrate food web based on stable isotope analyses. International journal of osteoarchaeology 16, 296-315.

Bouby, L., Zech-Matterne, V., Bouchette, A., Cabanis, M., Derreumaux, M., Dietsch-Sellami, M.- F., Durand, F., Figueiral, I., Marinval, P. and Pradat, B. in press. Ressources et économie agricole en France à l'âge du Bronze et au premier âge du Fer. État des données carpologiques, in Carozza, L., Marcigny, C. and Talon, M. (eds.), L'habitat et l'occupation du sol à l'âge du Bronze et au début du premier âge du Fer, actes de la table ronde sur la restitution de l'enquête nationale. Bayeux: Inrap/CNRS éditions.

Brettell, R., Montgomery, J. and Evans, J. 2012. Brewing and stewing: the effect of culturally mediated behaviour on the oxygen isotope composition of ingested fluids and the implications for human provenance studies. Journal of Analytical Atomic Spectrometry 27, 778-85.

Bruzek J. 2002. A method for visual determination of sex, using the human hip bone. American Journal of Physical Anthropology 117(2), 157-68.

Cabanis, M. and Mennessier-Jouannet, C., avec la collaboration de Bouby L., Hajnalova M., and Wiethold J. 2010. Economie végétale en Basse Auvergne, à l'Age du Bronze et au premier Age du Fer, pp. 67-84 in Delhon, C., Théry-Parisot, I. and Thiébault, S. (eds.), Des Hommes et des plantes. Exploitation du milieu et des ressources végétales de la Préhistoire à nos jours. Antibes: APDCA.

Chambon, P., Rottier, S., Augereau, A., Bonnardin, S., Meunier, K. and Pariat, J.- G. 2013. Evolution, coexistence et confrontation de pratiques funéraires entre 4700 et 4000 av. J.-C. sur un microterritoire dans la vallée de l'Yonne. Actes du XXVIIe congrès préhistorique de France. Société préhistorique française 1, 213-27.

Clavel, B. 2009. Site de pêche néolithique au bord de l'Aisne. Archéopages 26, 22-3.

Clavel, B. and Arbogast, R. M. 2007. Fish exploitation from early neolithic sites in northern France: The first data, pp. 85-91 in Leidorf, C. D. (ed.), The Role of Fish in Ancient Time, 13th Meeting of the International Council of the ICAZ Fish Remains Working Group. Basel: Internationale Archäologie.

Cramp, L. J. E., Jones, J., Sheridan, A., Smyth, J., Whelton, H., Mulville, J., Sharples, N. and Evershed, R. P. 2014. Immediate replacement of fishing with dairying by the earliest farmers of the northeast Atlantic archipelagos. Proceedings of the Royal Society - Biological sciences 100, 1524-9.

DeNiro, M. J. 1985. Postmortem preservation and alteration of in vivo bone collagen isotope ratios in relation to palaeodietary reconstruction. Nature 317, 806-9.

Dürrwächter, C., Craig, O. E., Collins, M., Burger, J. and Alt, K. W. 2006. Beyond the grave: variability in Neolithic diets in southern Germany? Journal of Archaeological Science 33, $39-48$.

Earl, T. and Kristiansen, K. 2010. Organizing Bronze Age Societies. Cambridge: University Press.

Farquhar, G. D., Ehleringer, J. R. and Hubick, K. T. 1989. Carbon isotope discrimination and photosynthesis. Annual Review of Plant Physiology and Plant Molecular Biology 40, 503-37.

Ferrage-Toulemonde, F. 2013. Économie végétale et pratiques agricoles au Bronze final et au premier âge du Fer, de la côte de l'Île-de-France à la côte de Champagne. Unpublished $\mathrm{PhD}$ dissertation, Université Paris I.

Froehle, A. W., Kellner, C. M. and Schoeninger, M. J. 2012. Multivariate carbon and nitrogen stable isotope model for the reconstruction of prehistoric human diet. American Journal of Physical Anthropology 147, 352-69.

Giligny, F. (ed.), 2005. Louviers "la Vilette" (Eure) : un site Néolithique moyen en zone humide. Rennes: Documents Archéologiques de l'Ouest.

Goude, G., Balasescu, A., Reveillas, H., Thomas, Y. and Lefranc, P. 2014. Diet variability and stable isotope analyses: looking for variables within the late neolithic and iron age human groups 
from Gougenheim site and surrounding areas (Alsace, France). International Journal of Osteoarchaeology 25, 988-96.

Goude, G. and Fontugne, M. 2016. Carbon and nitrogen isotopic variability in bone collagen during the Neolithic period: Influence of environmental factors and diet. Journal of Archaeological Science 70, 117-31.

Goude, G., Schmitt, A., Herrscher, E., Loison, G., Cabut, S. and André, G. 2013. Pratiques alimentaires au Néolithique moyen: Nouvelles données sur le site de Pontcharaud 2 (Auvergne, France). Bulletin de la Société Préhistorique Française 110, 299-317.

Guilaine, J. 2007. Le Chalcolithique et la construction des inégalités, T. 1 \& 2. Paris: Errance, coll. "Des Hesperides".

Hajnalova, M., Barta, P. and Terrasi, F. 2013. Radiocarbon dating of the earliest finds of proso millet Panicum miliaceum in the northern part of Carpathian Basin. Abstracts book, 16th Conference of the International Work Group for Palaeoethnobotany. 17-22 June 2013, Thessaloniki, p.48.

Harding, A. F. 2000. European Societies in the Bronze Age. Cambridge: Cambridge University Press.

Harding, A. F. and Fokkens, H. 2013. The Oxford Handbook of the European Bronze Age. Oxford: University Press.

Hedges, R. E. M. 2003. On bone collagen-apatite-carbonate isotopic relationships. International Journal of Osteoarchaeology 13, 66-79.

Herrscher, E. in press. La place de l'exploitation des pêcheries de Saint-Jean-le-Thomas dans l'approvisionnement alimentaire: analyses isotopiques des restes animaux et humains, pp. 172-6 in Billard, C., and Bernard, V. (eds.), Archéologie et histoire des pêcheries littorales du département de la Manche: Direction régionale des affaires culturelles de BasseNormandie. Caen: SRA.

Herrscher, E., Goude, G., Lisfranc, R., Forest, V. and Vermeulen, C. 2013. Restitution des pratiques alimentaires au Bronze ancien en Auvergne par l'analyse isotopique des ossements animaux et humains. Préhistoires méditerranéennes $\mathbf{4}$, http://pm.revues. org $/ 782$

Hu, Y., Ambrose, S. H. and Wang, C. 2006. Stable isotopic analysis of human bones from Jiahu site, Henan, China: implications for the transition to agriculture. Journal of Archaeological Science 33, 1319-30.

Hu, Y., Wang, S., Luan, F., Wang, C. and Richards, M. P. 2008. Stable isotope analysis of humans from Xiaojingshan site: implications for understanding the origin of millet agriculture in China. Journal of Archaeological Science 35, 2960-5.

Hunt, H. V., Vander Linden, M., Liu, X., Motuzaite-Matuzeviciute, G., Colledge, S. and Jones, M. K. 2008. Millets across Eurasia: chronology and context of early records of the genera Panicum and Setaria from archaeological sites in the Old World. Vegetation History and Archeobotany 17, 5-18.

Iacumin, P., Bocherens, H., Mariotti, A. and Longinelli, A. 1996. An isotopic palaeoenvironmental study of human skeletal remains from the Nile Valley. Palaeogeography, Palaeoclimatology, Palaeoecology 126, 15-30.

Jacob, Jérémy, Disnar, Jean-Robert and Bardoux, Gérard. 2008. "Carbon isotope evidence for sedimentary miliacin as a tracer of Panicum miliaceum (broomcorn millet) in the sediments of Lake le Bourget (French Alps)," organic geochemistry. Advances in Organic Geochemistry 2007 - Proceedings of the 23rd International Meeting on Organic Geochemistry 39(8), 1077-80.

Kellner, C. M. and Schoeninger, M. J. 2007. A simple carbon isotope model for reconstructing prehistoric human diet. American Journal of Physical Anthropology 133, 1112-27.

King, S. R. B. and Gurnell, J. 2005. Habitat use and spatial dynamics of takhi introduced to Hustai National Park, Mongolia. Biological Conservation 124, 277-90.

van Klinken, G. J. 1999. Bone collagen quality indicators for palaeodietary and radiocarbon measurements. Journal of Archaeological Science 26, 687-95.

Knudson, K. J. 2009. Oxygen isotope analysis in a land of environmental extremes: the complexities of isotopic work in the Andes. International Journal of Osteoarchaeology 19, 171-91.

Kristiansen, K. 1998. The formation of Tribal systems in Northern Europe, 4000-500 BC, pp. 70-105 in Kristiansen, K. and Rowlands, M. (eds.), Social Transformations in Archaeology, Global and Local Perspectives. London - New York: Routledge.

Kristiansen, K. and Rowlands, M. 1998. Social Transformations in Archaeology, Global and Local Perspectives. London New York: Routledge.
Krueger, H. W. and Sullivan, C. H. 1984. Models for carbon isotope fractionation between diet and bone, pp. 205-20 in Turnlund, J. and Johnson, P. (eds.), Stable Isotopes in Nutrition. Washington: American Chemical Society.

Le Bras-Goude, G., Lisfranc, R., Loison, G., Forest, V. and Herrscher, E. 2011. The Bronze Age diet in Auvergne (France): a stable isotope approach. American Journal of Physical Anthropology 144(S52), 195-6.

Le Luyer, M., Rottier, S. and Bayle, P. 2014. Brief communication: Comparative patterns of enamel thickness topography and oblique molar wear in two early Neolithic and medieval population samples. American Journal of Physical Anthropology 155, $162-72$.

Lebon, M., Müller, K., Bahain, J.-J., Fröhlich, F., Falguères, C., Bertrand, L., Sandt, C. and Reiche, I. 2011. Imaging fossil bone alterations at the microscale by SR-FTIR microspectroscopy. Journal of Analytical Atomic Spectrometry 26, 922-9.

Lebon, M., Reiche, I., Bahain, J.-J., Chadefaux, C., Moigne, A.-M., Fröhlich, F., Sémah, F., Schwarcz, H. P. and Falguères, C. 2010. New parameters for the characterization of diagenetic alterations and heat-induced changes of fossil bone mineral using Fourier Transform Infrared Spectrometry. Journal of Archaeological Science 37, 2265-76.

Lee-Thorp, J., Sealy, J. C. and van der Merwe, N. 1989. Stable carbon isotope ratio differences between bone collagen and bone apatite, and their relationship to diet. Journal of Archaeological Science 16, 585-99.

Lightfoot, E., Liu, X. and Jones, M. K. 2013. Why move starchy cereals? A review of the isotopic evidence for prehistoric millet consumption across Eurasia. World Archaeology 45(4), 574-623.

Longin, R. 1971. New method of collagen extraction for radiocarbon dating. Nature 230, 241-2.

Longinelli, A. 1984. Oxygen isotopes in mammal bone phosphate: A new tool for paleohydrological and paleoclimatological research? Geochimica et Cosmochimica Acta 48, 385-90.

Magny, M. 2004. Holocene climate variability as reflected by midEuropean lake-level fluctuations and its probable impact on prehistoric human settlements. Quaternary International 113, 65-79.

Magny, M., Bossuet, G., Gauthier, E., Richard, H., Vannière, B., Billaud, Y., Marguet, A. and Mouthon, J. 2007. Variations du climat pendant l'Âge du Bronze au centre-ouest de l'Europe: vers l'établissement d'une chronologie à haute résolution, pp. 13-28 in Richard, H., Magny, M. and Mordant, C. (eds.), Environnements et Cultures à l'Âge du Bronze en Europe occidentale. Paris : CTHS.

Mariotti, A. 1982. Apport de la géochimie isotopique à la connaissance du cycle de l'azote. Unpublished $\mathrm{PhD}$ dissertation, Université Paris VI.

Mihlbachler M. C., Rivals, F., Solounias, N., and Semprebon, G. M. 2011. Dietary change and evolution of horses in North America. Science 331, 1178.

Motuzaite-Matuzeviciute, G., Staff, R. A., Hunt, H. V., Liu, X. and Jone, M. K. 2013. The early chronology of broomcorn millet (Panicum miliaceum) in Europe. Antiquity 87, 1073-85.

Motuzaite-Matuzeviciute, G., Lightfoot, E., O'Connell, T. C., Voyakin, D., Liu, X., Loman, V., Svyatko, S., Usmanova, E. and Jones, M. K. 2015. The extent of cereal cultivation among the Bronze Age to Turkic period societies of Kazakhstan determined using stable isotope analysis of bone collagen. Journal of Archaeological Science 59, 23-34.

Murail, P., Bruzek, J., Houët, F. and Cunha, E. 2005. DSP: a tool for probabilistic sex diagnosis using worldwide variability in hipbone measurements. Bulletins et Mémoires de la Société d'Anthropologie de Paris, n.s., 17(3-4), 167-76.

Naito, Y. I., Chikaraishi, Y., Ohkouchi, N., Drucker, D. and Bocherens, H. 2013. Nitrogen isotopic composition of collagen amino acids as an indicator of aquatic resource consumption: Insights from Mesolithic and Epipalaeolithic archaeological sites in France. World Archaeology 45, 338-59.

Nehlich, O., Boric, D., Stefanovic, S. and Richards, M. P. 2010. Sulphur isotope evidence for freshwater fish consumption: a case study from the Danube Gorges, SE Europe. Journal of Archaeological Science 37, 1131-9.

O'Connell, T. C., Kneale, C. J., Tasevska, N. and Kuhnle, G. G. C. 2012. The diet-body offset in human nitrogen isotopic values: a controlled dietary study. American Journal of Physical Anthropology 149, 426-34.

R Core Team. 2016. R: A language and environment for statistical computing. R Foundation for Statistical Computing, Vienna, Austria. URL http://www.R-project.org/. 
Rey, L. 2013. Comportements alimentaires au Néolithique : étude isotopique de la nécropole de Gurgy "Les Noisats », Yonne (Bassin parisien). Unpublished Master dissertation, Université Bordeaux 1.

Rey, L., Goude, G. and Rottier, S. 2013. Comportements alimentaires au Néolithique: nouveaux résultats isotopiques dans le Bassin parisien. Bulletins et Mémoires de la Société d'Anthropologie de Paris 26, S32.

Richard, H., Magny, M. and Mordant, C. 2007. Environnements et cultures à l'âge du Bronze en Europe occidentale. Paris: CTHS.

Richards, M. P. 2003. Explaining the dietary isotope evidence for the rapid adoption of the Neolithic in Britain, pp. 31-6 in Parker Pearson, M. (ed.), Food Culture and Identity in the Neolithic and Early Bronze Age. Oxford: B.A.R. International Series.

Richards, M. P. and Hedges, R. E. M. 1999. A Neolithic revolution? New evidence of diet in the British Neolithic. Antiquity 73, 891-7.

Richards, M. P. and Schulting, R. J. 2003. Archaeology: Sharp shift in diet at onset of Neolithic. Nature 425, 366.

Rivollat, M., Mendisco, F., Pemonge, M. H., Safi, A., Saint-Marc, D., Brémond, A., Couture-Veschambre, C., Rottier, S. and Deguilloux, M. F. 2015. When the waves of European Neolithization met: first paleogenetic evidence from early farmers in the Southern Paris Basin. PlosOne, April 30, 2015 DOI:10.1371/journal.pone.0125521

Rottier, S. 2004. Pratiques funéraires de l'étape initiale du Bronze final dans les bassins de l'Yonne et de la Haute-Seine : L'exemple des sites funéraires de Barbuise - Courtavant - La Saulsotte et Barbey aux XIVème, XIIIème et XIIème siècles avant J.-C. Bulletin de la Société Préhistorique Française 101, 614-20.

Rottier, S., Mordant, C., Chambon, P. and Thevenet, C. 2007 Découverte de plus d'une centaine de sépultures du Néolithique moyen à Gurgy, les Noisats (Yonne). Bulletin de la Société Préhistorique Française 102, 641-5.

Rottier, S. 2009. Fonctionnement des tombes du début du Bronze final (XIV-XIIème s. av. J.-C.) dans le Sud-Est du Bassin parisien (France). Bulletins et Mémoires de la Société d'Anthropologie de Paris 21, 19-46.

Rottier, S. 2011. Sépultures différentes, pratique commune : le cas du complexe funéraire de Barbuise et La Saulsotte (Aube) au début du Bronze final, pp. 161-80 in Castex, D., Courtaud, P., Duday, H., Le Mort, F. and Tillier, A.- M. (eds.), Le regroupement des morts : genèse et diversité archéologique. Bordeaux : Ausonius, Maison des Sciences de l'homme d'Aquitaine.

Rottier, S. 2012. Archéologie funéraire du Bronze final dans les vallées de l'Yonne et de la haute Seine. Dijon: Editions Universitaires de Dijon.

Rottier, S. 2015. The social skin and the hypothesis of an uxorilocal system in the early late Bronze Age (14th-12th BC) in the Southeast of the Paris Basin, pp. 131-39 in SuchowskaDucke, P., Reiter, S. and Vandkilde, H. (eds.), Forging Identities. The Mobility of Culture in Bronze Age Europe: Volume 1, Proceedings of the Congress, 2-6 June 2012 Aarhus, Denmark.

Rottier, S. 2016. The seated dead: evidence of funerary complexity from the early late Bronze Age, 14th-12th centuries BC in France. Journal of Archaeological Science, Reports, Special Issue Funerary Taphonomy. doi:10.1016/j.jasrep.2016.04.016.

Rottier, S., Mordant, C., Chambon, P. and Thévenet, C. 2005. Découverte de plus d'une centaine de sépultures du Néolithique moyen à Gurgy, les Noisats (Yonne). Bulletin de la Société Préhistorique Française 102, 641-5.

Rottier, S., Piette, J. and Mordant, C. 2012. Archéologie funéraire du Bronze final dans les vallées de l'Yonne et de la haute Seine: les nécropoles de Barbey, Barbuise et La Saulsotte. Dijon: Editions Universitaires de Dijon.

Rowlands, M. 1998. Kinship, alliance and exchange in the European Bronze Age, pp. 142-82 in Kristiansen, K. and Rowlands, M. (eds.), Social Transformations in Archaeology, Global and Local Perspectives. London - New York: Routledge.

Salesse, K., Dufour, E., Lebon, M., Wurster, C., Castex, D., Bruzek, J. and Zazzo, A. 2014. Variability of bone preservation in a confined environment: The case of the catacomb of Sts Peter and Marcellinus (Rome, Italy). Palaeogeography, Palaeoclimatology, Palaeoecology 416, 43-54.

Schaefer, M., Black, S. and Scheuer, L. 2009. Juvenile Osteology. A Laboratory and Field Manual. London: Elsevier.
Schoeninger, M. J. and DeNiro, M. J. 1983. Nitrogen and carbon isotopic composition of bone collagen from marine and terrestrial animals. Geochimica et Cosmochimica Acta 48, 625-39.

Schoeninger, M. J., De Niro, M. J. and Tauber, H. 1983. Stable Nitrogen isotope ratios of bone collagen reflect marine and terrestrial components of prehistoric human diet. Science 220, 1381-3.

Schulting, R. and Richards, M. P. 2002. The wet the wild and the domesticated: the Mesolithic-Neolithic transition of the west of Scotland. European Journal of Archaeology 5, 147-89.

Schwarcz, H. P. 1991. Some theoretical aspects of isotope paleodiet studies. Journal of Archaeological Science 18, 261-75.

Silence, A. and LeGeros, R. Z. 1991. Solubility profiles of synthetic apatites and of modern and fossil bones. Journal of Archaeological Science 18, 385-97.

Stevens, R. E., Lightfoot, E., Allen, T. and Hedges, R. E. M. 2012. Palaeodiet at Eton College Rowing Course, Buckinghamshire: isotopic changes in human diet in the Neolithic, Bronze Age, Iron Age and Roman periods throughout the British Isles. Archaeological and Anthropological Sciences 4, 167-84.

Stika, H.-P. and Heiss, A. G. 2013. Plant cultivation in the Bronze age, pp. 348-69 in Fokkens, H. and Harding, A. (eds.), The Oxford Handbook of the European Bronze Age. Oxford: Oxford University Press.

Tafuri, M. A., Craig, O. E. and Canci, A. 2009. Stable isotope evidence for the consumption of millet and other plants in Bronze Age Italy. American Journal of Physical Anthropology 139, 146-53.

Tarrête, J. and Le Roux, C.-T. (Dir.), 2008. Le Néolithique. Archéologie de la France. Paris: Editions du Ministère de la Culture et de la Communication.

Tauber H. 1981. 13C evidence for dietary habits of prehistoric man in Denmark. Nature 292, 332-3.

Tieszen, L. L. and Boutton, T. W. 1989. Stable carbon isotopes in terrestrial ecosystem research, pp. 167-95 in Rundel, P. W. Ehleringer, J. R. and Nagy, K. A. (eds.), Stable Isotopes in Ecological Research. New York: Springer-Verlag.

Toulemonde, F., Zech-Matterne, V., Wiethold, J., Brun, C., Malrain, F. and Riquier, V., avec la collaboration de Durand F. forthcoming. Evolution des modes de production agricole au cours du ler millénaire av. n. e. dans l'est de la France : propositions d'après l'analyse carpologique des adventices, Actes du 39e colloque international de l'AFEAF, Nancy, 14-17 Mai 2015.

Tresset, A. 1990. Chasse élevage et alimentation carnée chez les premiers paysans de la vallée de la Petite Seine (fin du Ve-début du IIIe millénaire avant notre ère). Mémoire de l'Académie des Sciences arts et belles lettres de Dijon 131, 199-208.

Valentin, J. 2003. Basic Anatomical and Physiological Data for Use in Radiological Protection: Reference Values. ICRP Publication 89. London: Pergamon, Elsevier.

Varalli A. 2015. Ricostruzione delle strategie di sussistenza in Italia durante l'età del Bronzo: il contributo delle analisi isotopiche. $\mathrm{Ph} \mathrm{D}$. thesis. Aix-Marseille Université/Università di Firenze, Aix en Provence/Firenze.

Varalli, A., Goude, G., and Del Lucchese, A. 2012-2013. Dal Neolitico all'Età del Ferro: indagine paleonutrizionale su alcune popolazioni della Liguria attraverso un approccio isotopico. Archeologia in Liguria 5, 11-9.

Varalli, A., Moggi-Cecchi, J., and Goude G. 2013. What do Italian people eat during Bronze Age? The evolution of the Italian diet through the comparison of food pattern analyzed by stable isotopes $(\mathrm{C}, \mathrm{N})$. Bulletins et Mémoires de la Société d'Anthropologie de Paris 26, S42.

Varalli, A., Moggi-Cecchi, J. and Goude, G. 2014. Evolution of the dietary patterns in Bronze Age Italy through stable isotopes analysis. American Journal of Physical Anthropology 153(S58), 260

Varalli, A., Moggi-Cecchi, J., Moroni, A. and Goude, G. 2016. Dietary variability during Bronze Age in central Italy: first results. International Journal of Osteoarchaeology 26, 431-46.

Virginia, R. A. and Delwiche, C. C. 1982. Natural $15 \mathrm{~N}$ abundance of presumed N2 fixing and non N2 fixing plants from selected ecosystems. Oecologia 54, 317-25.

Weiner, S., Goldberg, P. and Bar-Yosef, O. 1993. Bone preservation in Kebara Cave, Israel using on-site fourier transform infrared spectrometry. Journal of Archaeological Science 20, 613-27.

Zazzo, A. 2001. Validation méthodologique de l'utilisation des compositions isotopiques $(13 \mathrm{C}, 18 \mathrm{O})$ des bioapatites fossiles pour la reconstitution des paléoenvironnements continentaux. Unpublished $\mathrm{PhD}$ Thesis, Université Pierre et Marie Curie, Paris 6. 